University of Nebraska - Lincoln

DigitalCommons@University of Nebraska - Lincoln

2010

\title{
A Black Hills-Madison Aquifer Origin for Dakota Aquifer Groundwater in Northeastern Nebraska
}

\author{
Randy Stotler \\ University of Nebraska - Lincoln, rlstotle@uwaterloo.ca \\ F. Edwin Harvey \\ University of Nebraska - Lincoln, feharvey1@unl.edu \\ David C. Gosselin \\ University of Nebraska - Lincoln, dgosselin2@unl.edu
}

Follow this and additional works at: https://digitalcommons.unl.edu/natrespapers

Part of the Natural Resources and Conservation Commons

Stotler, Randy; Harvey, F. Edwin; and Gosselin, David C., "A Black Hills-Madison Aquifer Origin for Dakota Aquifer Groundwater in Northeastern Nebraska" (2010). Papers in Natural Resources. 184.

https://digitalcommons.unl.edu/natrespapers/184

This Article is brought to you for free and open access by the Natural Resources, School of at DigitalCommons@University of Nebraska - Lincoln. It has been accepted for inclusion in Papers in Natural Resources by an authorized administrator of DigitalCommons@University of Nebraska - Lincoln. 
Published in Ground Water (2010); doi: 10.1 III/j.I745-6584.2009.00636.x Copyright (C 2009 Randy Stotler, F. Edwin Harvey, and David C. Gosselin; journal compilation @ 2010 National Ground Water Association. Published by John Wiley Inc. Used by permission.

Submitted July 2008, accepted August 2009; published online October 14, 2009.

\title{
A Black Hills-Madison Aquifer Origin for Dakota Aquifer Groundwater in Northeastern Nebraska
}

\author{
Randy Stotler, F. Edwin Harvey, and David C. Gosselin \\ School of Natural Resources, University of Nebraska-Lincoln, Lincoln, NE 68583-0996 \\ Corresponding author - R. Stotler, current address: Department of Earth and Environmental Sciences, University of Waterloo, Waterloo, \\ Ontario, Canada N2L 3G I; tel 519 888-4567, x37277, fax 519 746-7484, email rlstotle@uwaterloo.ca \\ Co-authors email _ feharveyl@unl.edu \& dgosselin2@unl.edu
}

\begin{abstract}
Previous studies of the Dakota Aquifer in South Dakota attributed elevated groundwater sulfate concentrations to Madison Aquifer recharge in the Black Hills with subsequent chemical evolution prior to upward migration into the Dakota Aquifer. This study examines the plausibility of a Madison Aquifer origin for groundwater in northeastern Nebraska. Dakota Aquifer water samples were collected for major ion chemistry and isotopic analysis $\left({ }^{18} \mathrm{O},{ }^{2} \mathrm{H},{ }^{3} \mathrm{H},{ }^{14} \mathrm{C},{ }^{13} \mathrm{C},{ }^{34} \mathrm{~S},{ }^{18} \mathrm{O}-\mathrm{SO}_{4},{ }^{87} \mathrm{Sr},{ }^{37} \mathrm{Cl}\right)$. Results show that groundwater beneath the eastern, unconfined portion of the study area is distinctly different from groundwater sampled beneath the western, confined portion. In the east, groundwater is calcium-bicarbonate type, with $\delta^{18} \mathrm{O}$ values $(-9.6 \%$ o to $-12.4 \%$ ) similar to local, modern precipitation $(-7.4 \%$ o to $-10 \%$ ), and tritium values reflecting modern recharge. In the west, groundwater is calcium-sulfate type, having depleted $\delta^{18} \mathrm{O}$ values $(-16 \%$ o to $-18 \%$ o) relative to local, modern precipitation, and ${ }^{14} \mathrm{C}$ ages 32,000 to more than 47,000 years before present. Sulfate, $\delta^{18} \mathrm{O}, \delta^{2} \mathrm{H}, \delta^{34} \mathrm{~S}$, and $\delta^{18} \mathrm{O}-$ $\mathrm{SO}_{4}$ concentrations are similar to those found in Madison Aquifer groundwater in South Dakota. Thus, it is proposed that Madison Aquifer source water is also present within the Dakota Aquifer beneath northeastern Nebraska. A simple Darcy equation estimate of groundwater velocities and travel times using reported physical parameters from the Madison and Dakota Aquifers suggests such a migration is plausible. However, discrepancies between ${ }^{14} \mathrm{C}$ and Darcy age estimates indicate that ${ }^{14} \mathrm{C}$ ages may not accurately reflect aquifer residence time, due to mixtures of varying aged water.
\end{abstract}

\section{Introduction}

Background

The Great Plains (Dakota) Aquifer and its hydrostratigraphic equivalents extend from the Arctic Circle to New Mexico, and from the eastern edge of the Rocky Mountains to Iowa and Minnesota (Jorgenson et al. 1993). Upham (1895) and Darton (1905) first conceptualized the Dakota Aquifer as a continuous sandstone unit that was recharged along the flanks of the Black Hills and Rocky Mountains. In this model, groundwater flowed eastward beneath the Central Great Plains, eventually discharging along the aqui- fer's eastern limit in North and South Dakota, Nebraska, and Kansas. The first regional potentiometric surface map of the Dakota Aquifer was constructed by Darton (1905), and later refined by Helgesen et al. $(1982,1984)$ and Leonard et al. (1984) (Figure 1). Compared with the earliest survey conducted by Darton (1909), piezometric head declines as large as $79 \mathrm{~m}$ were noted as early as the 1950s (Barkley 1953) in artesian areas of the Dakota Aquifer.

Swenson (1968) later refined this conceptual model, proposing that groundwater within the Dakota Aquifer in eastern South Dakota had actually been recharged into the underlying Madison (limestone) Aquifer along the flanks of the Black Hills, subsequently flowed eastward, and dis- 


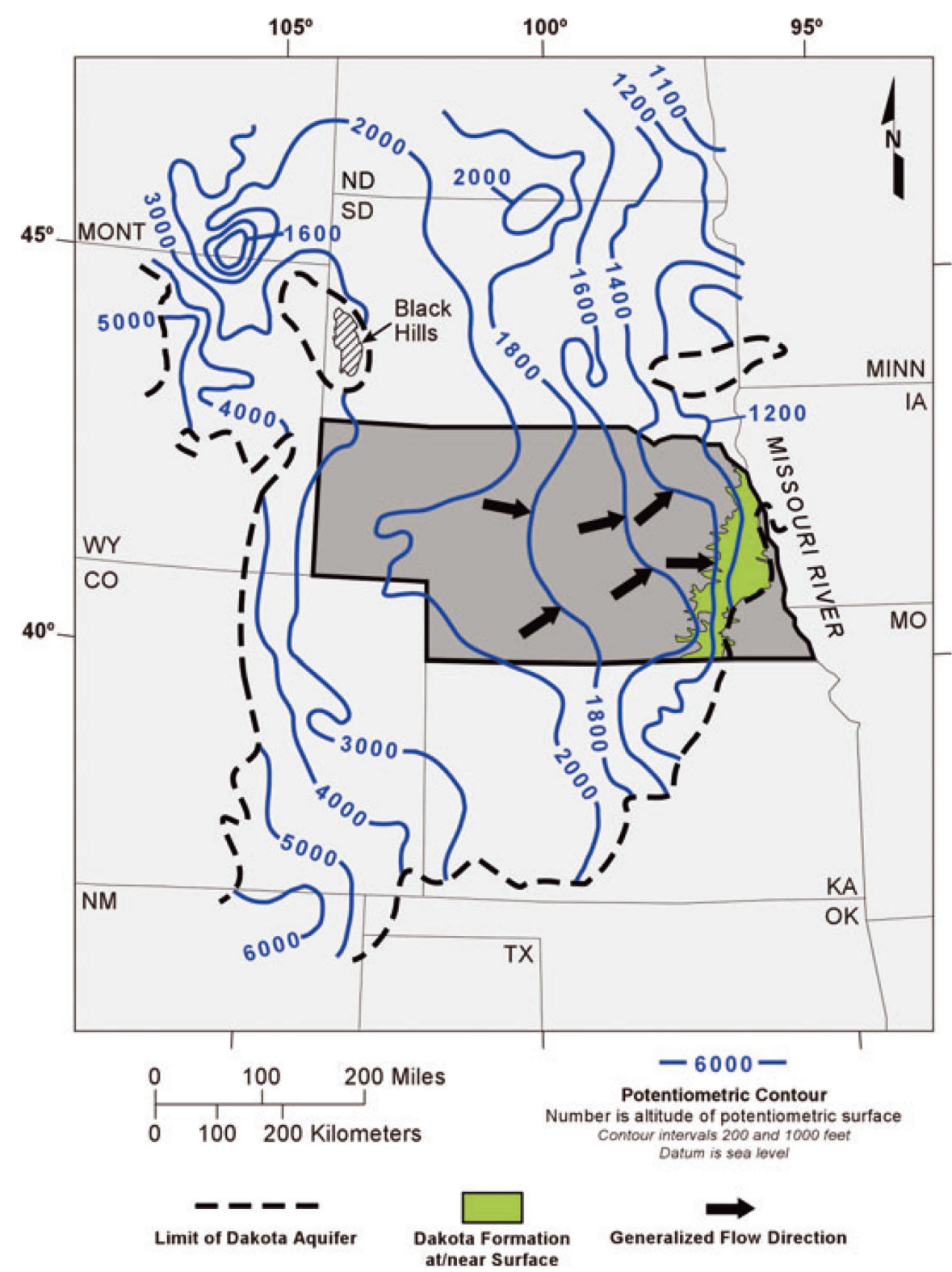

Figure 1. Recent potentiometric surface map of the Dakota Aquifer (modified from Leonard et al., 1984) and the location of the Black Hills in South Dakota.

charged upward into the Dakota Aquifer. Madison groundwater, with a sulfate chemistry derived from the dissolution of anhydrite, had migrated upward from the Madison Aquifer into the Dakota Aquifer in the area where the Madison limestone pinches out beneath the Dakota sandstone (Swenson 1968).

This proposed groundwater flow system was modeled by Bredehoeft et al. (1983), using a numerical groundwater flow model. They concluded that upward leakage from lower units was the predominant source of sulfate in the Dakota Aquifer, that model calculated concentrations were consistent with those observed, and with the Swenson (1968) concept of flow within the system. They also state that based on their computations, approximately
$25 \%$ of the groundwater present in the Dakota Aquifer came from the Madison Aquifer (Bredehoeft et al. 1983).

A limited water quality survey of the Great Plains (Dakota) Aquifer system across eastern Nebraska (Figure 2) located an area in which groundwater had elevated temperatures, high dissolved sulfate concentrations, and isotopically light $\delta^{18} \mathrm{O}$ and $\delta^{2} \mathrm{H}$ signatures relative to the local mean precipitation (Gosselin et al. 2001; Harvey 2001). As a more detailed follow-up to the earlier survey, the current study collected and analyzed additional water samples in this area from wells screened in the Dakota Aquifer, providing the opportunity to test long-standing hydraulic arguments for Madison Aquifer recharge to the Dakota Aquifer utilizing chemical and isotopic data. 


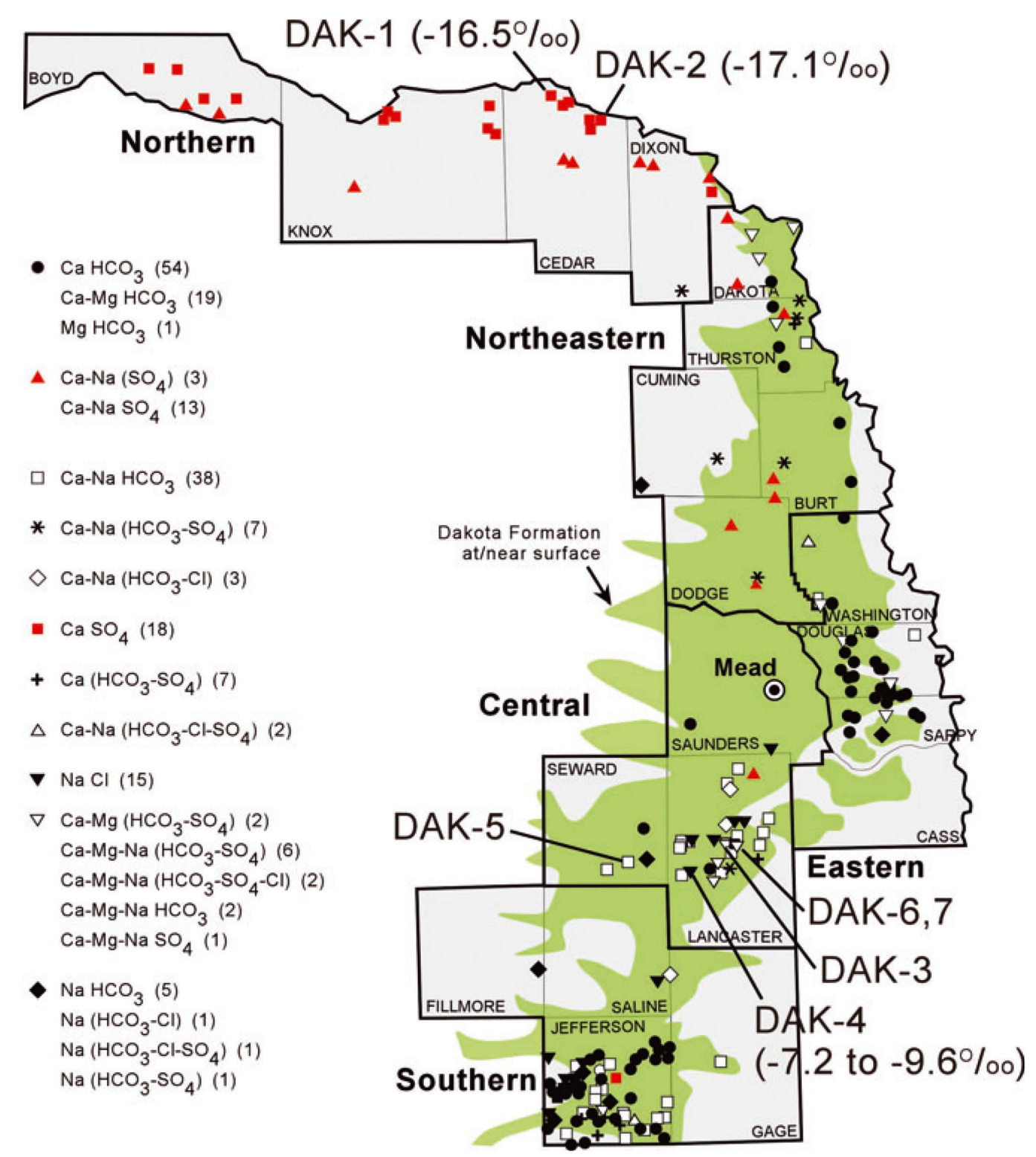

Figure 2. Summary of results of geochemical survey conducted by Gosselin et al. (2001) showing northeastern region of high sulfate, depleted $\delta^{18} \mathrm{O}$ and $\delta^{2} \mathrm{H}$ values.

\section{Site Description}

This study was conducted in Boyd, Knox, Cedar, Dixon, Dakota, and Thurston counties in northeastern Nebraska and Yankton County in South Dakota (Figure 3), as these counties lie within and near the region of the high sulfate, isotopically depleted water reported by Gosselin et al. (2001) (Figure 2). The Dakota Aquifer system underlies the entire region of the study. In Thurston, Dakota, and parts of Dixon counties, the Dakota sandstones occur as outcrops (Figure 3). Various Quaternary deposits of glacial till overly the Dakota Formation in these counties. Farther west, in Dixon, Cedar, Knox, and Boyd counties, the Dakota sandstones are overlain by other Cretaceous formations, including the Greenhorn-Graneros limestone and shale, Carlile Shale, Niobrara Chalk, Pierre Shale, and various Tertiary and Quaternary deposits (Figure 3). Artesian conditions are present within the Dakota Aquifer in this area. The Greenhorn-Graneros, Carlile, Niobrara, and Pierre Formations, primarily marine shale units, act as confining units to the Dakota Aquifer. In parts of the study area, the Dakota Aquifer overlies several formations of various ages and lithology, including Ordovician, Mississippian, and Pennsylvanian deposits, and the Precambrian Sioux Quartzite. The Dakota Formation thickens from less than $30 \mathrm{~m}$ in eastern Colorado to $185 \mathrm{~m}$ in northeast Nebraska, exceeding $260 \mathrm{~m}$ in central Nebraska (Gosselin et al. 2001), and varies in depth from more than 1200 $\mathrm{m}$ in the west to surface outcrops in the east and northeast. A more detailed summary of the geology of the Dakota Formation in the study area may be found in Gosselin et al. (2001, 2004). 


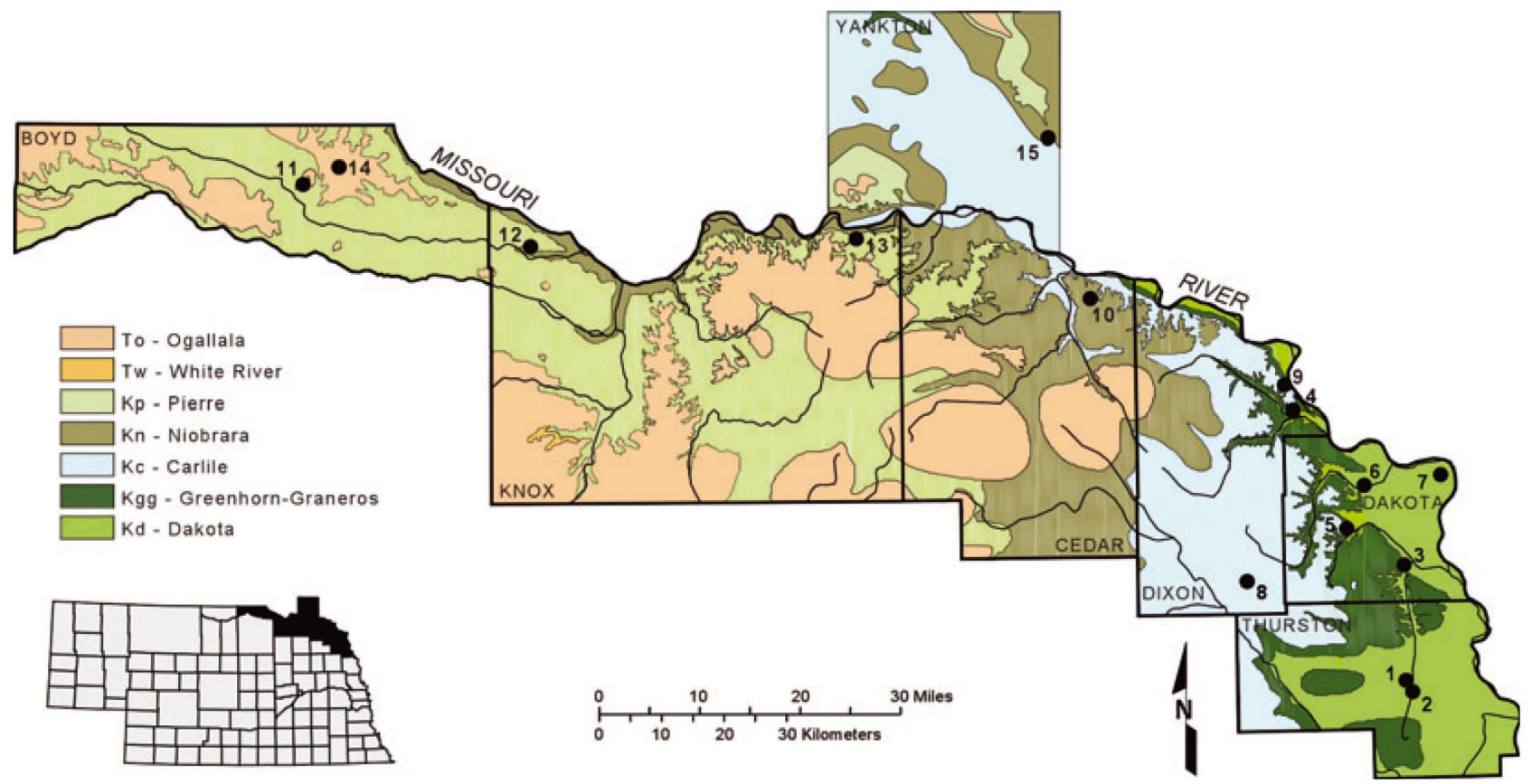

Figure 3. Map of bedrock geology of eastern Nebraska (modified from Burchett and Pabian, 1991). This study's 14 sample well locations are also plotted.

\section{Methods}

\section{Well Locations}

Fourteen wells were selected in northeastern Nebraska and southeastern South Dakota for sampling, following an extensive evaluation of state water well records at the $\mathrm{Ne}$ braska Conservation and Survey Division (the state geological survey), the local U.S. Geological Survey well database for the region, and field interviews with local well owners and Natural Resource District personnel. The selected wells were municipal production wells, irrigation wells, or domestic wells. Although several were screened over large intervals of the aquifer, and it was recognized that interformational mixing could be a potential problem, the wells were deemed acceptable for a large-scale study of a regional aquifer. Drillers' well logs (on file at the Nebraska Conservation and Survey Division and the South Dakota Geological Survey for each of the wells) were used to verify that each of the selected wells was screened in the Dakota Aquifer.

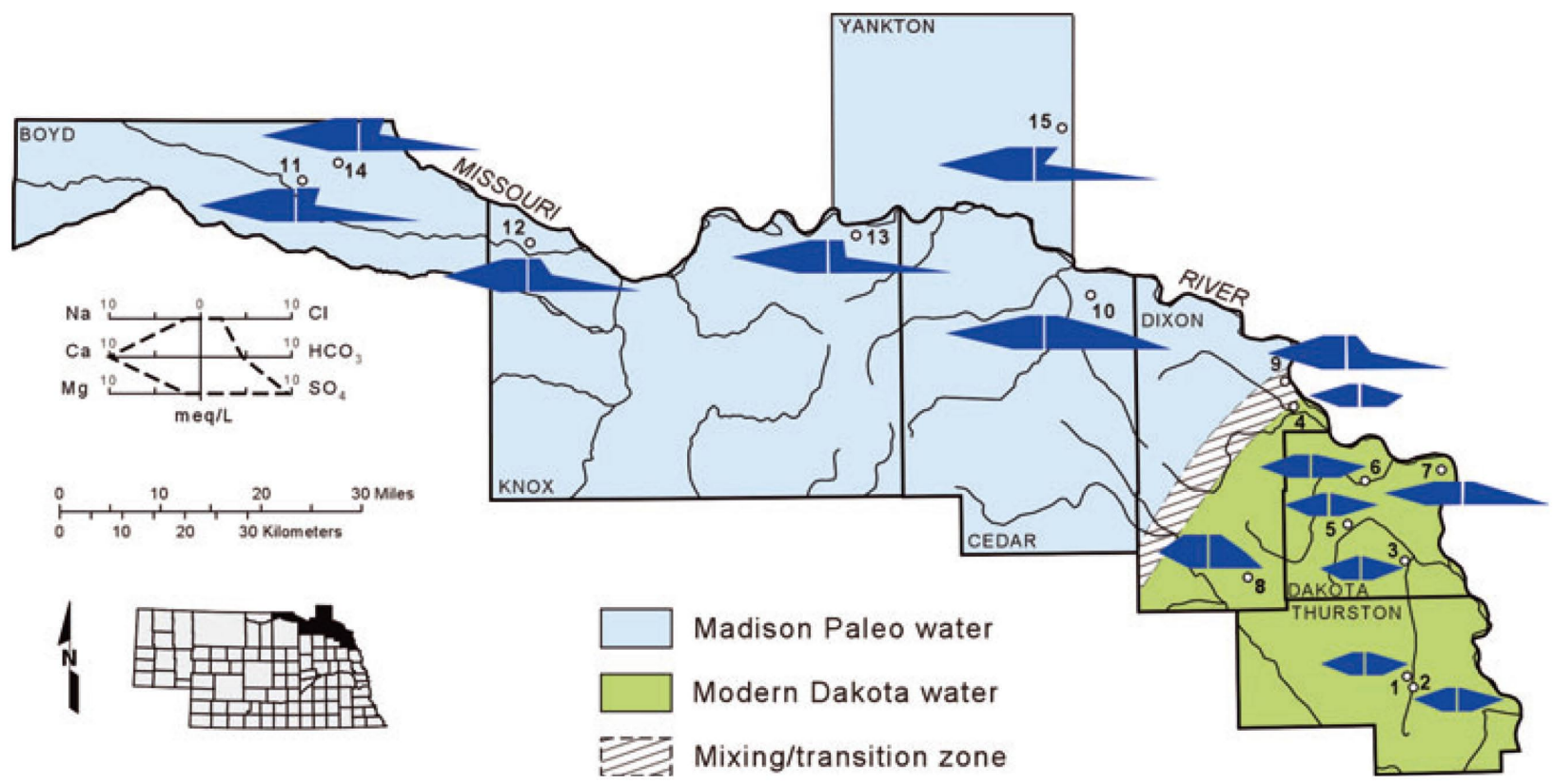

Figure 4. Map of study area groundwater chemistry (Stiff diagrams). 


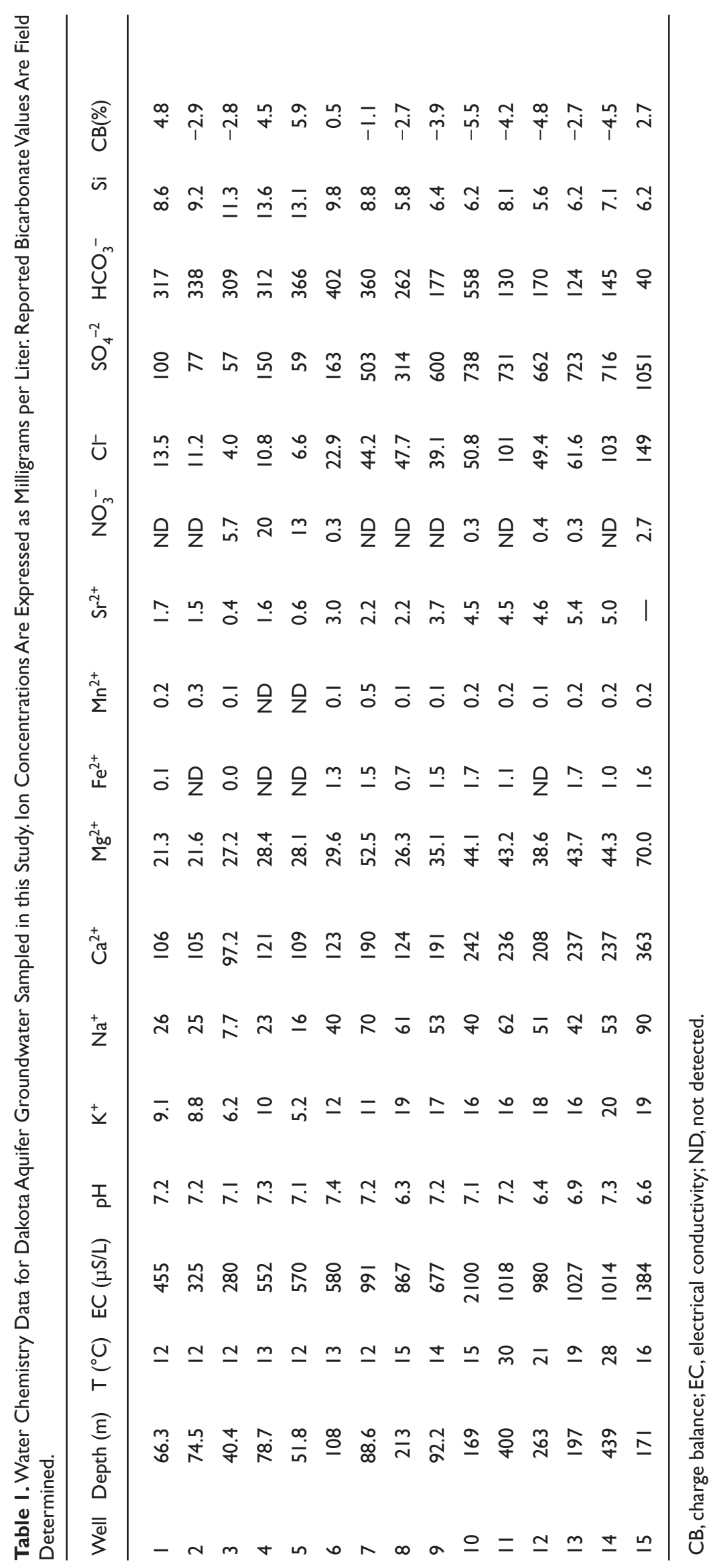




\section{Chemical and Isotope Sampling}

Before sampling, each well was pumped for a minimum of $10 \mathrm{~min}$. Samples were taken as close to the vertical pump column as possible. A flow-through sampling system was set up to minimize the effects of atmospheric interaction on temperature and $\mathrm{pH}$ during field analysis. Water samples for cation, anion, and alkalinity analysis were filtered through a $0.45-\mathrm{m}$ Whatman ${ }^{\circledR}$ (WhatmanGE Healthcare, http://www.whatman.com/) cellulose nitrate membrane prior to collection in $60 \mathrm{~mL}$ bottles, using a Nalgene ${ }^{\circledR}$ (Thermo Fisher Scientific, International Department, 75 Panorama Creek Drive, Rochester, NY 14625 USA, http://www.nalgenelabware.com/) filter apparatus and Mityvac ${ }^{\circledR}$ (Lincoln Customer Service, One Lincoln Way, St. Louis, MO 63120, http://www.mityvac.com/) hand-held pump. Water samples collected for cation analysis were preserved by adding two to three drops of concentrated $(17 \mathrm{M})$ nitric acid $\left(\mathrm{HNO}_{3}\right)$ to lower the $\mathrm{pH}$ to less than 4.0. Water samples for stable isotope $\left(\delta^{18} \mathrm{O}, \delta^{2} \mathrm{H}\right)$, enriched tritium $\left({ }^{3} \mathrm{H}\right)$, carbon-14 $\left({ }^{14} \mathrm{C}\right)$, carbon-13 $\left(\delta^{13} \mathrm{C}\right)$, and sulfur isotope $\left(\delta^{34} \mathrm{~S}, \delta^{18} \mathrm{O}-\mathrm{SO}_{4}\right)$ analysis were collected in $125,125,1000,1000$, and $125 \mathrm{~mL}$ bottles, respectively, and sealed free of trapped air for later analysis. All samples were collected in polyethylene bottles, with the exception of several enriched tritium samples, which were collected in glass bottles. Samples were transported and stored at approximately $4^{\circ} \mathrm{C}$ prior to analysis.

\section{Chemical and Isotope Analyses}

Temperature, conductivity, and $\mathrm{pH}$ values were measured in the field using Orion ${ }^{\circledR}$ meters and probes with accuracies of $\pm 0.1^{\circ} \mathrm{C}, \pm 10 \mu \mathrm{S} / \mathrm{cm}$, and $\pm 0.05 \mathrm{pH}$ units, respectively. Field alkalinity was determined using an $\mathrm{HACH}^{\circledR}$ (HACH Company, P.O. Box 389, Loveland, CO 80539 USA, http://www.hach.com/) digital titrator. Inorganic chemical analyses were carried out at the University of NebraskaLincoln's Soil and Plant Analytical Laboratory. Cation $\left(\mathrm{K}^{+}\right.$, $\mathrm{Na}^{+}, \mathrm{Ca}^{+2}, \mathrm{Mg}^{+2}, \mathrm{Fe}^{+2}, \mathrm{Mn}^{+2}$, and $\mathrm{Sr}^{+2}$ ) and $\mathrm{SiO}_{2}$ (as $\mathrm{Si}$ ) concentrations were measured using flame atomic absorption (AA) spectrometry. Anion $\left(\mathrm{NO}_{3}{ }^{-}, \mathrm{Cl}^{-}, \mathrm{SO}_{4}{ }^{-2}\right.$, and $\mathrm{HCO}_{3}{ }^{-}$ ) concentrations were determined using ion chromatography (IC). Alkalinity as bicarbonate $\left(\mathrm{HCO}_{3}\right)$ was also determined in the lab by volumetric titration. Practical detection limits for ions with AA and IC were around $0.1 \mathrm{mg} / \mathrm{L}$ though the actual limits varied for each ion, and for each individual analysis so reported values were rounded up to negate any errors or spread in the data around the detection limit (see Supporting Information). A charge balance (CB) was calculated for each analysis to evaluate analytical error, and to determine if all the major ions were accounted for in the analysis. CBs were calculated using the equation $\mathrm{CB}$, where concentrations of cations and anions are in $\mathrm{mEq} / \mathrm{L}($ as $\%)=\left[\left(\Sigma_{\text {cations }}-\Sigma_{\text {anions }}\right) /\left(\Sigma_{\text {cations }}+\Sigma_{\text {anions }}\right)\right] \times 100$. CBs between $\pm 5 \%$ are typically considered to be acceptable for most groundwater analyses.
Stable isotope analyses were performed at the Environmental Isotope Laboratory (EIL) at the University of Waterloo in Waterloo, Ontario, Canada. Stable oxygen, hydrogen, sulfur, oxygen of sulfate, carbon, and chlorine determinations were made using isotope ratio mass spectrometry following the procedures of Epstein and Mayeda (1953), Coleman et al. (1982), Yanagisawa and Sakai (1983), Shakur (1982), Gupta and Polach (1985), and Eggenkamp (1994), respectively. Oxygen, hydrogen, sulfur, oxygen of sulfate, carbon, and chlorine results are reported as parts per thousand (\%o) with respect to V-SMOW, V-SMOW, CDT, VSMOW, PDB, and SMOC, respectively, using the $(\delta)$ notation. The analytical precisions for $\delta^{18} \mathrm{O}, \delta^{2} \mathrm{H}, \delta^{34} \mathrm{~S}, \delta^{18} \mathrm{O}-\mathrm{SO}_{4^{\prime}}$ $\delta^{13} \mathrm{C}$, and $\delta^{37} \mathrm{Cl}$ are $0.2 \%$, $2.0 \%$ o, $0.2 \%$, $0.2 \%$, $0.2 \%$, and $0.2 \%$, respectively.

Tritium concentrations were determined by the electrolytic enrichment method of Taylor (1977), with a lower detection limit of 0.8 tritium units (TU). Tritium is reported in "TU".

Carbon-14 ages were determined using accelerator mass spectrometry at the Rafter Radiocarbon Laboratory of the Institute of Geological and Nuclear Sciences in New Zealand. The ${ }^{14} \mathrm{C}$ content is corrected for the $\delta^{13} \mathrm{C}$ value and reported according to the conventions of Stuiver and Polach (1977), and are reported as percent modern (PM), which are normalized based on $95 \%$ activity of the National Bureau of Standards (NBS) oxalic acid as modern standard, normalized for $\delta^{13} \mathrm{C}$ equal to $-19.0 \%$ o PDB. As normalized values are not desired for groundwater dating (Mook and van der Plicht 1999), the ${ }^{14} \mathrm{C}$ and PM values were then converted to a "denormalized" percent modern carbon (PMC) value following Mook and van der Plicht (1999). Further correction for elapsed time since the standard reporting year of 1950 was not conducted.

\section{Radiocarbon Corrections}

Dating groundwater by ${ }^{14} \mathrm{C}$ was first proposed by Munnich (1957), where the determined groundwater "age" refers to elapsed time since the water infiltrated deep enough into the saturated zone as to become isolated from the atmospheric $\mathrm{CO}_{2}$. Dissolution of carbonates along groundwater flowpaths can impact the measured age, and thus a correction is needed to account for the addition of dead carbon. Clark and Fritz (1997) and Kalin (2000) review several different methods for correcting groundwater ${ }^{14} \mathrm{C}$ ages. Given enough information about groundwater flow, geochemical evolution, and aquifer mineralogy, it is possible to account for the dilution of ${ }^{14} \mathrm{C}$; however, the number of different models available to correct for dilution show the difficulty in accounting for ${ }^{14} \mathrm{C}$ dilution (Clark and Fritz 1997; Kalin 2000). Furthermore, commentary by Zhu and Murphy (2000) and Bethke and Johnson (2002a, 2002b), for example, also point out the difficulty in using the ${ }^{14} \mathrm{C}$ dating method in regional scale, basinal systems as groundwater can be either older or younger than carbon ages depending on mixing dynamics and flowpath geometry. Recognizing 
and accepting these limitations, the ${ }^{14} \mathrm{C}$ age of groundwater within an aquifer still provides vital information related to relative recharge age and travel time. Thus, it will be used here to estimate the recharge age of water in the Dakota Aquifer in the study area, and to help estimate groundwater flow velocities and travel times from the recharge zone to the study area.

When corrected for dilution, the basic decay equation becomes: $t=-8267 \cdot \ln \left(a_{t}{ }^{14} \mathrm{C} / q \cdot a_{o}{ }^{14} \mathrm{C}\right)$, where $a_{t}{ }^{14} \mathrm{C}$ is the measured ${ }^{14} \mathrm{C}, a_{0}^{14} \mathrm{C}$ is the modern ${ }^{14} \mathrm{C}$ in soil, and $q$ is the dilution factor (Clark and Fritz 1997). For this study, dilution factors, $q$, were computed for the ${ }^{14} \mathrm{C}$ ages, using the alkalinity mass balance, chemical mass balance, and $\delta^{13} \mathrm{C}$ mixing models. For both the alkalinity chemical mass balance (CMB-Alk) correction (Tamers 1967; Fontes and Garnier 1979) and the carbonate, halite, gypsum dissolution with ion exchange (CMB-Chem) correction (Fontes and Garnier 1979), initial $\mathrm{pH}, \mathrm{pCO}_{2}, \mathrm{pKCO}_{2}$, and $\mathrm{pK} 1$ values were assumed to be $6,10^{-2.2}, 1.19$, and 6.52 , respectively, and were assumed typical of rain water recharging at $5^{\circ} \mathrm{C}$. For the $\delta^{13} \mathrm{C}$ mixing correction method (Ingerson and Pearson 1964; Pearson 1965; Pearson and Hanshaw 1970), stable carbon isotope $\left(\delta^{13} \mathrm{C}\right)$ values of dissolved carbonate and soil $\mathrm{CO}_{2}$ were assumed to be $0 \%$ and $-23 \%$, respectively. All of the correction models described so far considered an initial ${ }^{14} \mathrm{C}$ value of $100 \mathrm{PMC}$, are solvable in a spreadsheet, and provided similar results.

Radiocarbon age dilution corrections were also made utilizing NETPATH (Plummer et al. 1994). The NETPATH code considers different initial ${ }^{14} \mathrm{C}$ values by solving for eight different correction models, including chemical mass balance, electron balance, and isotope mass balance to define possible net geochemical reactions along a flowpath (Plummer et al. 1990).

\section{Results}

\section{Inorganic Chemistry}

The results of the chemical analysis of the study of groundwater are presented in Table 1 and are plotted on a map of the study area in Figure 4 using Stiff diagrams (Stiff 1951). Groundwater from the eastern portion of the study area (wells 1 to 6 ) is calcium-bicarbonate type water, having temperatures around $12^{\circ} \mathrm{C}$ to $13^{\circ} \mathrm{C}$. Groundwater from the western portion of the study area (wells 11 to 15) is calcium-sulfate type water, having higher temperatures between $16^{\circ} \mathrm{C}$ and $30^{\circ} \mathrm{C}$. This $\mathrm{Ca}-\mathrm{SO}_{4}$ water has much higher total dissolved solids (TDS) contents, with most of the major ion concentrations being higher. Much of this increase in TDS can be attributed to elevated sulfate and calcium concentrations. Strontium concentrations are also higher, and several well water $(11,14$, and 15) also have elevated chloride concentrations.

Groundwater from wells 7, 8, 9, and 10, located midway between wells within the two previously noted groups, has calcium-sulfate/bicarbonate type chemistries likely reflect- ing a mixed transition zoned between the eastern and western groundwater.

Stable Isotopes

As with the major ion chemistry, there is a clear distinction between eastern and western study area groundwater. Groundwater from wells 1 to 8 (Figure 5a) has $\delta^{18} \mathrm{O}$ and $\delta^{2} \mathrm{H}$ values in the range of $-9.6 \%$ o to $-12.4 \%$ and $-68 \%$ o to $-95 \%$, respectively. These are slightly lower than the weighted mean annual precipitation values $(-7.4 \%$ and $-48 \%$, respectively) reported for Mead, Nebraska (see Figure 2 for location relative to study area) by Harvey (2001) about $140 \mathrm{~km}$ to the south. However, these are similar to estimated ranges of values reported for northeastern Nebraska based on isotopic composition of stream samples in the region $(-8 \%$ o to $-10 \%$ for $\delta^{18} \mathrm{O}$ and $-60 \%$ o to $-18 \%$ o for $\delta^{2} \mathrm{H}$, Kendall and Coplen 2001) and ground water samples collected across the plains $\left(-9 \%\right.$ o for $\delta^{18} \mathrm{O}$ and $-60 \%$ or for $\delta^{2} \mathrm{H}$, Sheppard et al. 1969). Moving westward (Figure 5a), groundwater from wells 9 to 15 has a still lower signature $(-16 \%$ o to $-18.6 \%$ o) than groundwater to the east, and it is much lower than the weighted average precipitation values in the region suggesting recharge under different climatic conditions.

In addition to area groundwater, two surface water samples were also analyzed for comparison. Samples collected from the Missouri River (MR), near well 9 (Figure 5a), and Lewis and Clark Lake (LC), near well 10 (Figure 5a), at the northern edge of the study area had $\delta^{18} \mathrm{O}$ and $\delta^{2} \mathrm{H}$ values of $-12.9 \%$ and $-107 \%$, and $-13.2 \%$ and $-107 \%$, respectively. These are slightly lower values than predicted by Kendall and Coplen (2001) $(-10 \%$ o to $-8 \%$ and $-80 \%$ o to $-60 \%$ o for $\delta^{18} \mathrm{O}$ and $\delta^{2} \mathrm{H}$, respectively), but likely reflect a greater proportion of water from upstream, western sources, which would have lower isotopic values.

Like both the chemical and $\delta^{18} \mathrm{O}$ and $\delta^{2} \mathrm{H}$ values, $\delta^{34} \mathrm{~S}$ values showed notable differences from east to west (Figure $5 b$ ). Water from wells 1 to 9 has values less than $10 \%$, with wells 3 and 5 being negative, while in contrast, water from wells 10 to 15 has values greater than $10 \%$. There are differences in $\delta^{18} \mathrm{O}_{-} \mathrm{SO}_{4}$ values between wells (Figure $5 \mathrm{~b}$ ), but there may be no apparent correlation.

\section{Tritium and Carbon Age Dating Data}

Tritium concentrations are presented in Figure 5c. Dilution model corrected carbon-14 ages are presented in Table 2 and in Figure 5d. With the exception of wells 2 to 5, tritium concentrations were all below the detection limit suggesting an absence of modern tritium. Water sampled from wells 2 to 5 had detectable tritium concentrations, but each well's concentration was less than $10 \mathrm{TU}$. This suggests the presence of water that has recharged within the past 50 years. Carbon14 results range between $0.11+/-0.1$ and $55.12+/-0.4 \mathrm{PM}$ (Table 2). Corrected ages, calculated using several different methods (see Methods section), all gave similar ages of recent to about 50,000 years before present (ybp). Older dates 
(a) $\delta^{18} \mathrm{O}$ and $\delta^{2} \mathrm{H}\left({ }^{\circ} / 00\right)$

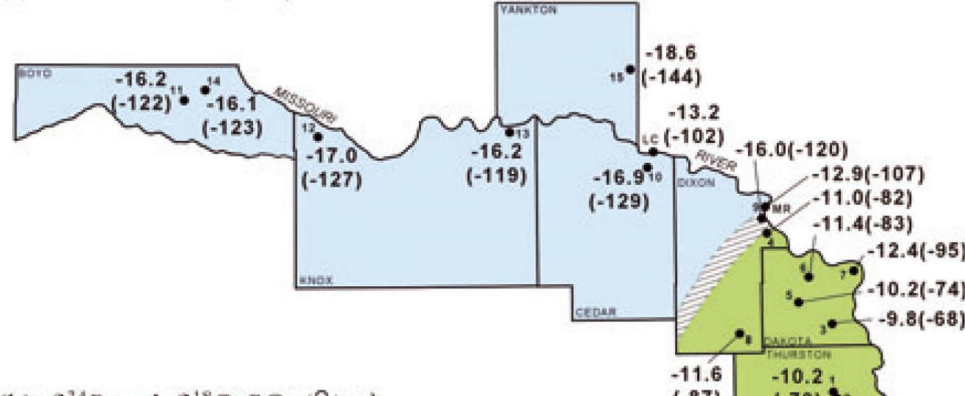

(b) $\delta^{34} \mathrm{~S}$ and $8^{18} \mathrm{O}-\mathrm{SO}_{4}(\%)$

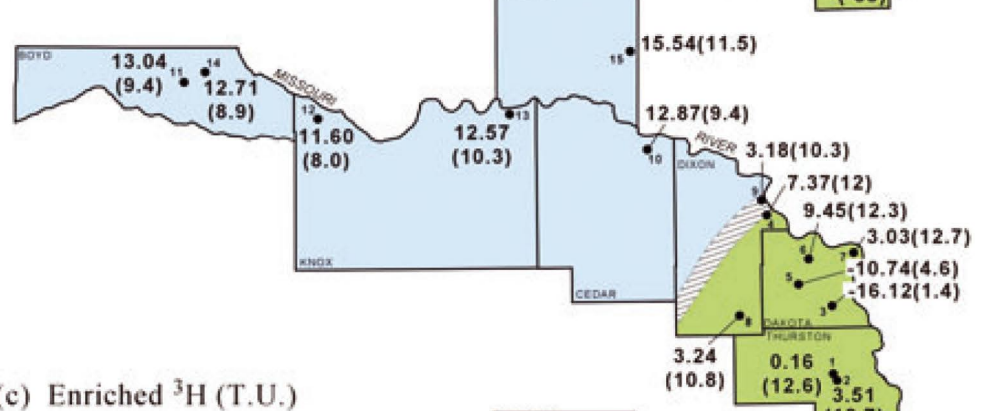

(c) Enriched ${ }^{3} \mathrm{H}(\mathrm{T}, \mathrm{U}$, ,
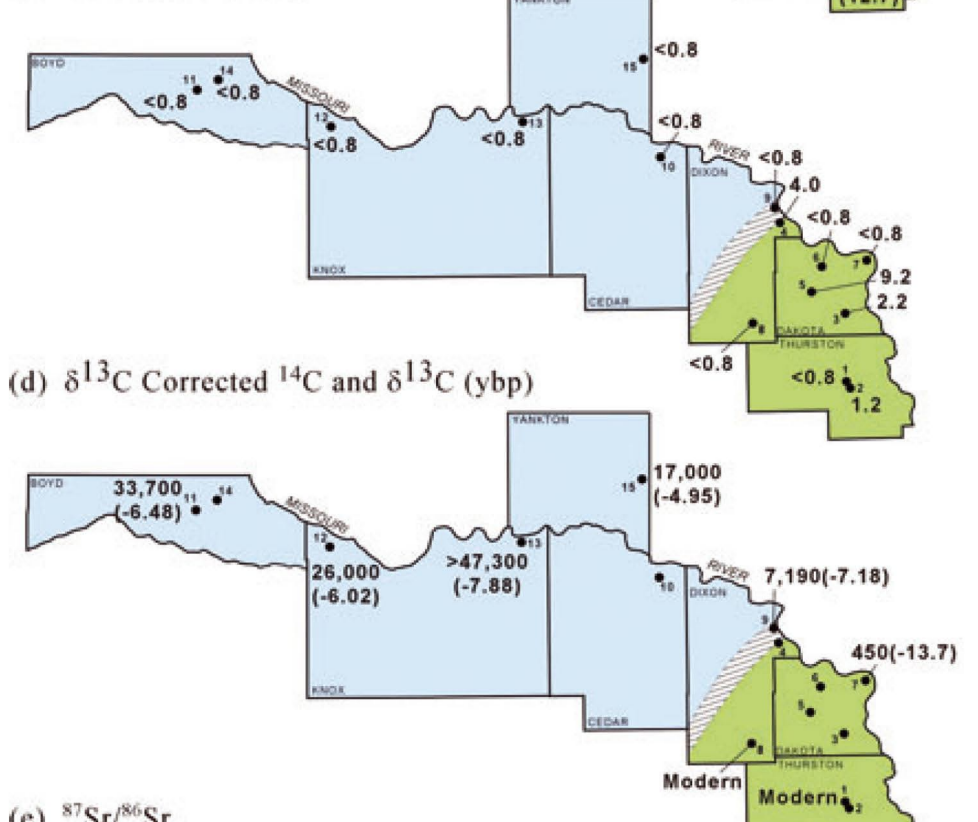

(e) ${ }^{87} \mathrm{Sr} /{ }^{86} \mathrm{Sr}$

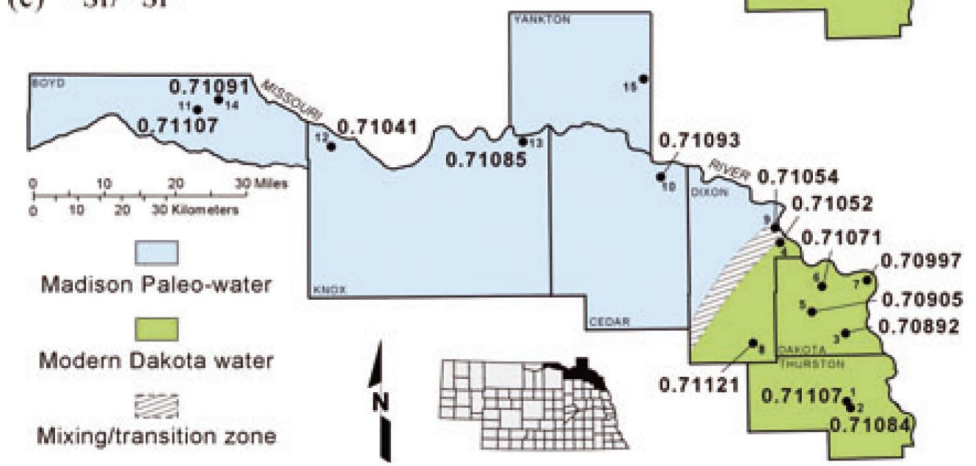

Figure 5. Maps showing values for: (a) $\delta^{18} \mathrm{O}$ and $\delta^{2} \mathrm{H}$ (in parentheses), (b) $\delta^{34} \mathrm{~S}$ and $\delta^{18} \mathrm{O}-\mathrm{SO} 4$ (in parentheses), (c) tritium, (d) $\delta^{13} \mathrm{C}$ corrected carbon-14 ages and $\delta^{13} \mathrm{C}$ (in parentheses), and (e) ${ }^{87} \mathrm{Sr} /{ }^{86} \mathrm{Sr}$. 


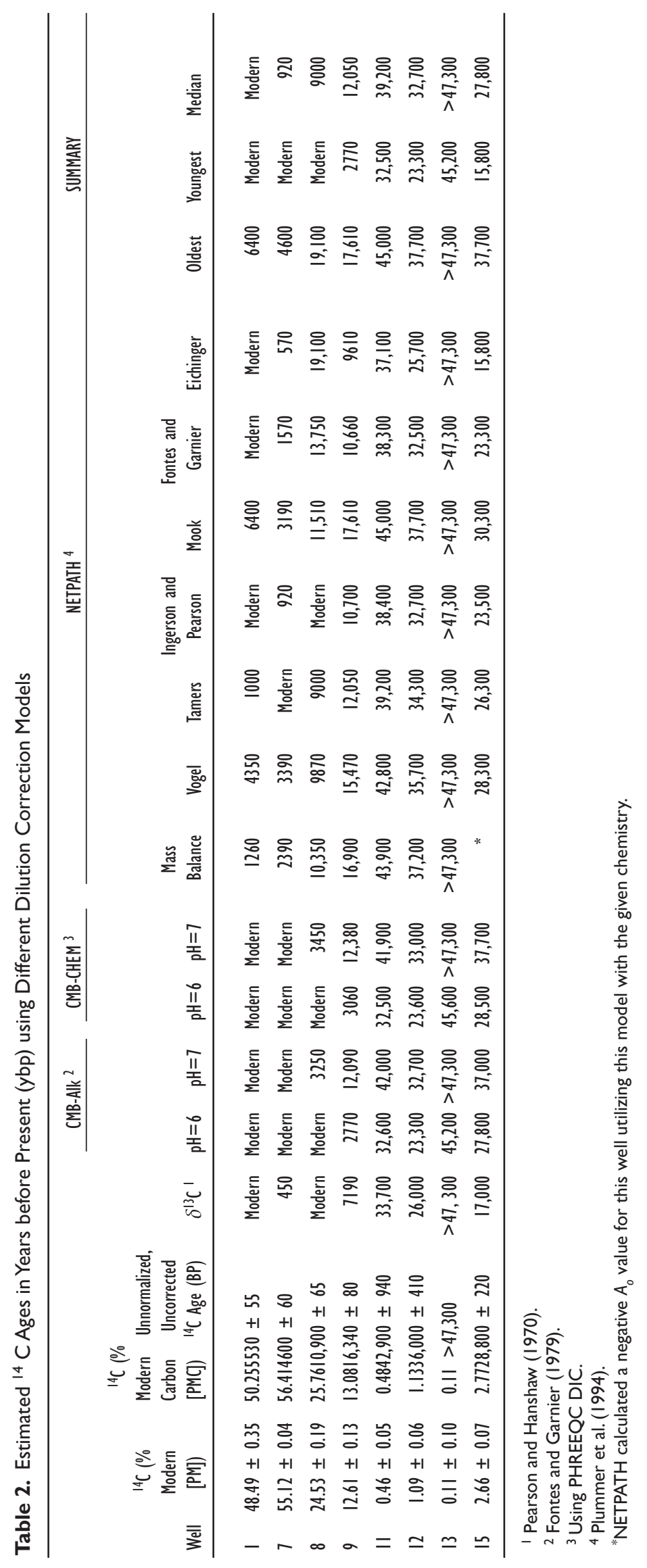




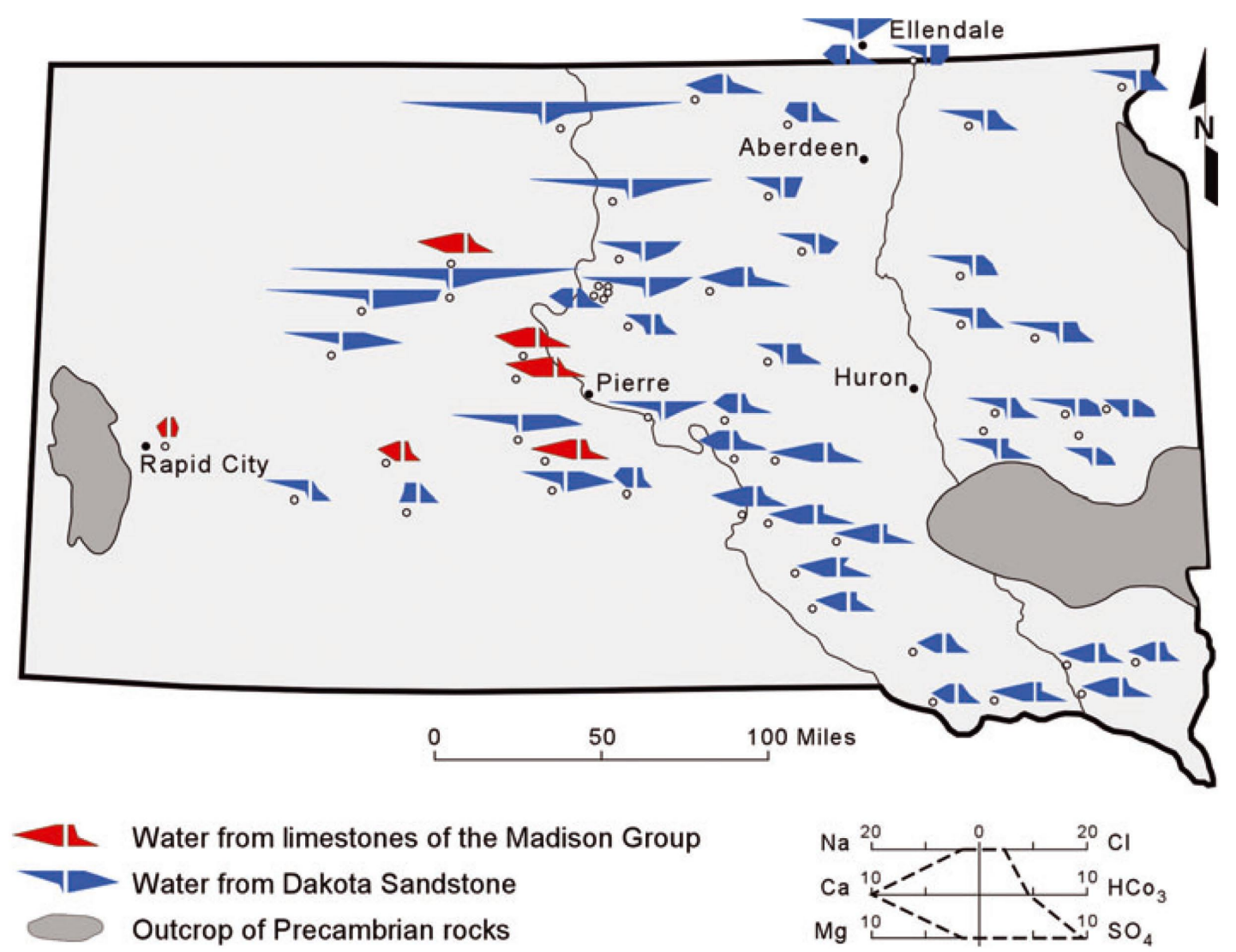

Figure 6. Map of South Dakota water chemistries (modified from Swenson, 1968).

were obtained for groundwater from the western wells (9 to 15). Using tritium and ${ }^{14} \mathrm{C}$ results, groundwater can be delineated into roughly three groups: modern water (less than 50 years), old water (those recharged during the last glacial period more than 15,000 years), and a group of intermediate age water which have ${ }^{14} \mathrm{C}$ ages younger than the end of the glacial age (less than 10,000 years), but older than modern recharge (more than 300 years).

\section{Discussion}

\section{Sulfate and Sulfur-34}

Groundwater in the western portion of the study area, where the Dakota Aquifer is confined, has elevated sulfate concentrations (Figure 4). Such high groundwater $\mathrm{SO}_{4}$ concentrations are not detected elsewhere in the Dakota Aquifer across eastern Nebraska (Gosselin et al. 2001). In areas where the Dakota units outcrop at the surface, or are overlain by pre-Illinoian glacial till, groundwater $\mathrm{SO}_{4}$ values vary between 31 and $130 \mathrm{mg} / \mathrm{L}$, but are much lower in concentration than the $\mathrm{Na}-\mathrm{Cl}$-type water sampled in the western part of the state (460 to $5700 \mathrm{mg} / \mathrm{L}$ ). So, the elevated dissolved sulfate concentrations sampled in the western portion of the study area may reflect a unique dissolution history related to regional flow patterns within the aquifer, which will be discussed in detail in the following paragraph.
Similar sulfate concentrations and major ion compositions were reported for groundwater in the Dakota Aquifer across the Missouri River in southeastern South Dakota by Swenson (1968) (Figure 6). Swenson (1968) proposed that groundwater within the Madison Formation was recharged along the flanks of the Black Hills, subsequently flowed eastward, and discharged upward into the Dakota Aquifer. Madison groundwater, with a sulfate chemistry derived from the dissolution of anhydrite, had migrated upward from the Madison Aquifer into the Dakota Aquifer in the area where the Madison limestone pinches out beneath the Dakota sandstone (Figure 7).

Water sampled for this study in the western part of the Dakota Aquifer study area has higher anhydrite and gypsum saturations than water in the east (see Table S1, Supporting Information). This suggests that groundwater in the downgradient, eastern area, where the Dakota outcrops at the surface, are mixtures of the older, more saturated, western groundwater and fresher, likely more recently and more locally recharged water. Western saturation indices compare well with values from the Madison Aquifer, which is undersaturated with respect to anhydrite and gypsum, but saturated with respect to calcite and dolomite, accompanying progressive anhydrite dissolution along various flowpaths (Plummer et al. 1990).

If the high sulfate groundwater in eastern Nebraska has at some point in its eastward migration passed through the Madison Aquifer, and has not been altered by sulfate reduc- 


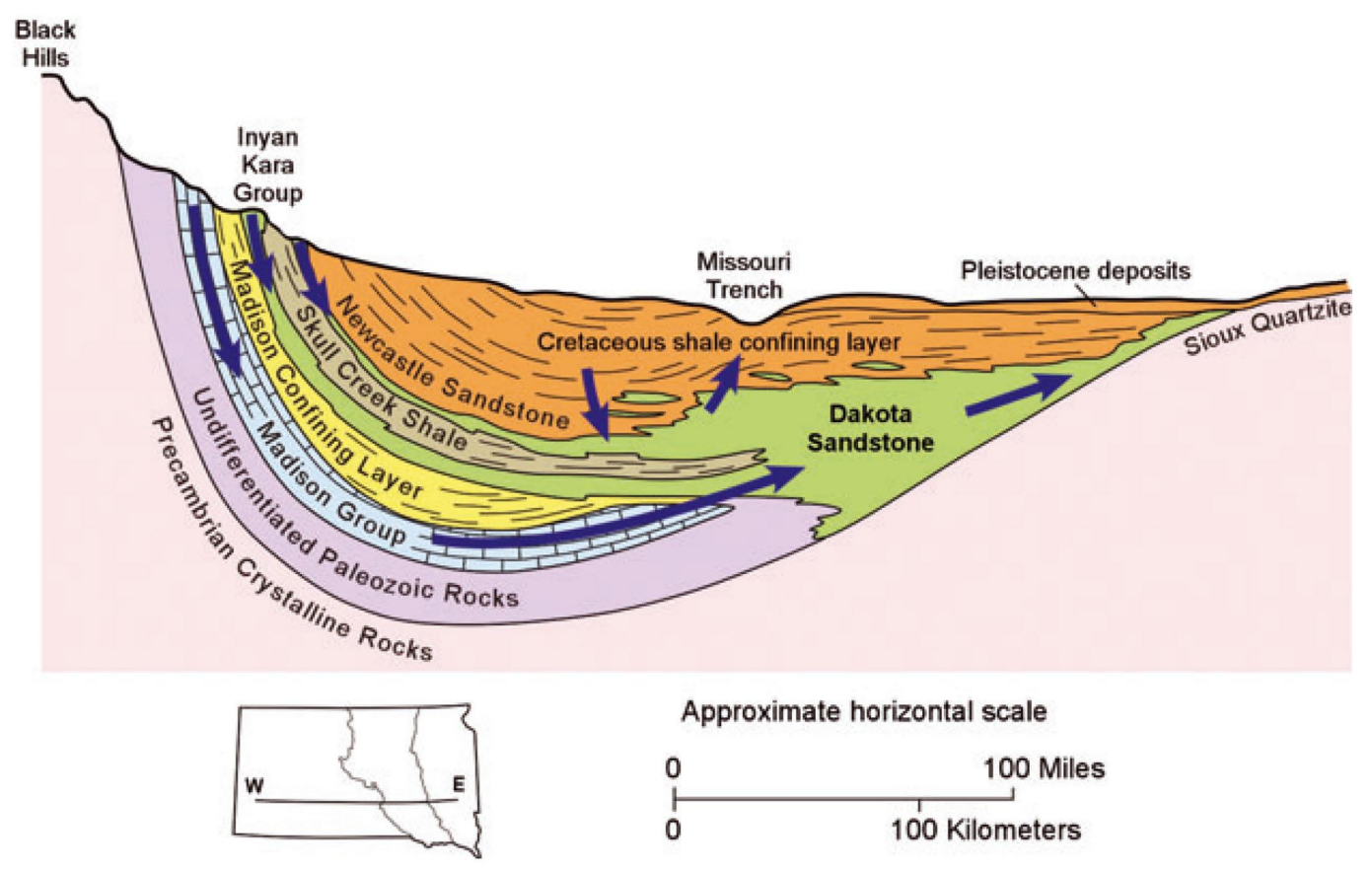

Figure 7. Regional W-E cross section of the Dakota Aquifer (modified from Bredehoeft et al., 1983).

tion or mixing with other sulfate sources, the sulfate-sulfur isotopic compositions should indicate a common history. The $\delta^{34} \mathrm{~S}$ and $\delta^{18} \mathrm{O}-\mathrm{SO}_{4}$ isotopic compositions of sampled sulfate in the western portion of study area are similar to established marine evaporate isotopic values (Figure 8). Toward the eastern portion of the study area, $\delta^{34} S$ values become less enriched in ${ }^{34} \mathrm{~S}$. The western Dakota $\delta^{34} \mathrm{~S}_{-} \mathrm{SO}_{4}$ isotopic compositions (11.60\% to $15.54 \%$ o) are similar to the isotopic values sampled in Madison Aquifer wells (11.36\% to $14.96 \%$ )
(Plummer et al. 1990), closest to the area the Madison Aquifer recharges the Dakota Aquifer (Figure 9). The source of the high dissolved sulfate in the Madison Aquifer was determined to be the irreversible dissolution of anhydrite as a driving force for dedolomitization, with some sulfate reduction and cation exchange, along the flowpath through South Dakota (Plummer et al. 1990). The sulfur isotopic data from the study area support a dissolved marine evaporite source for the dissolved sulfate sampled in the Dakota Aquifer,

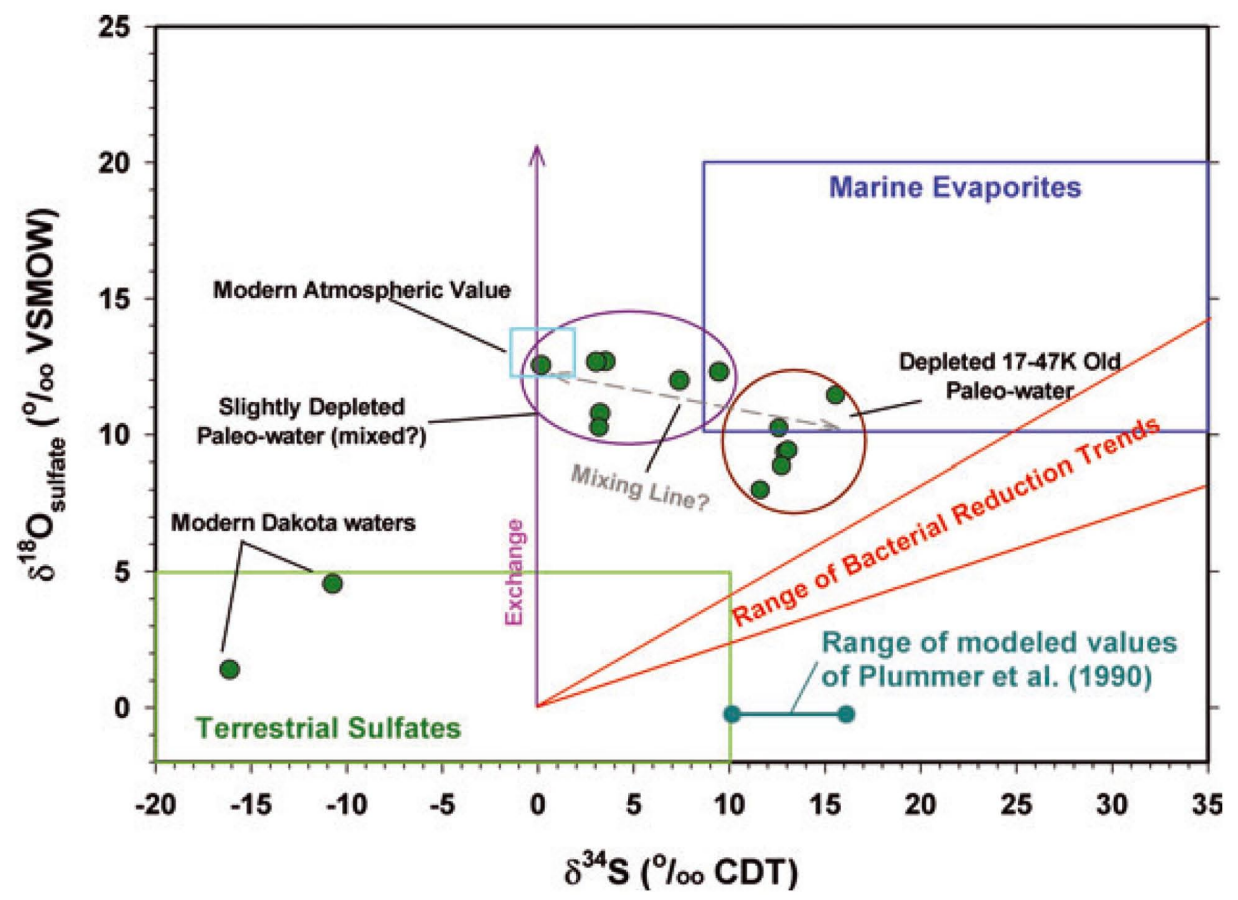

Figure 8. Plot of $\delta^{18} \mathrm{O}-\mathrm{SO}_{4}$ vs. $\delta^{34}$ S. The marine evaporite and terrestrial sulfate zones, exchange, and bacterial reduction trends are displayed based in the manuscript by Krouse and Mayer (2000). 


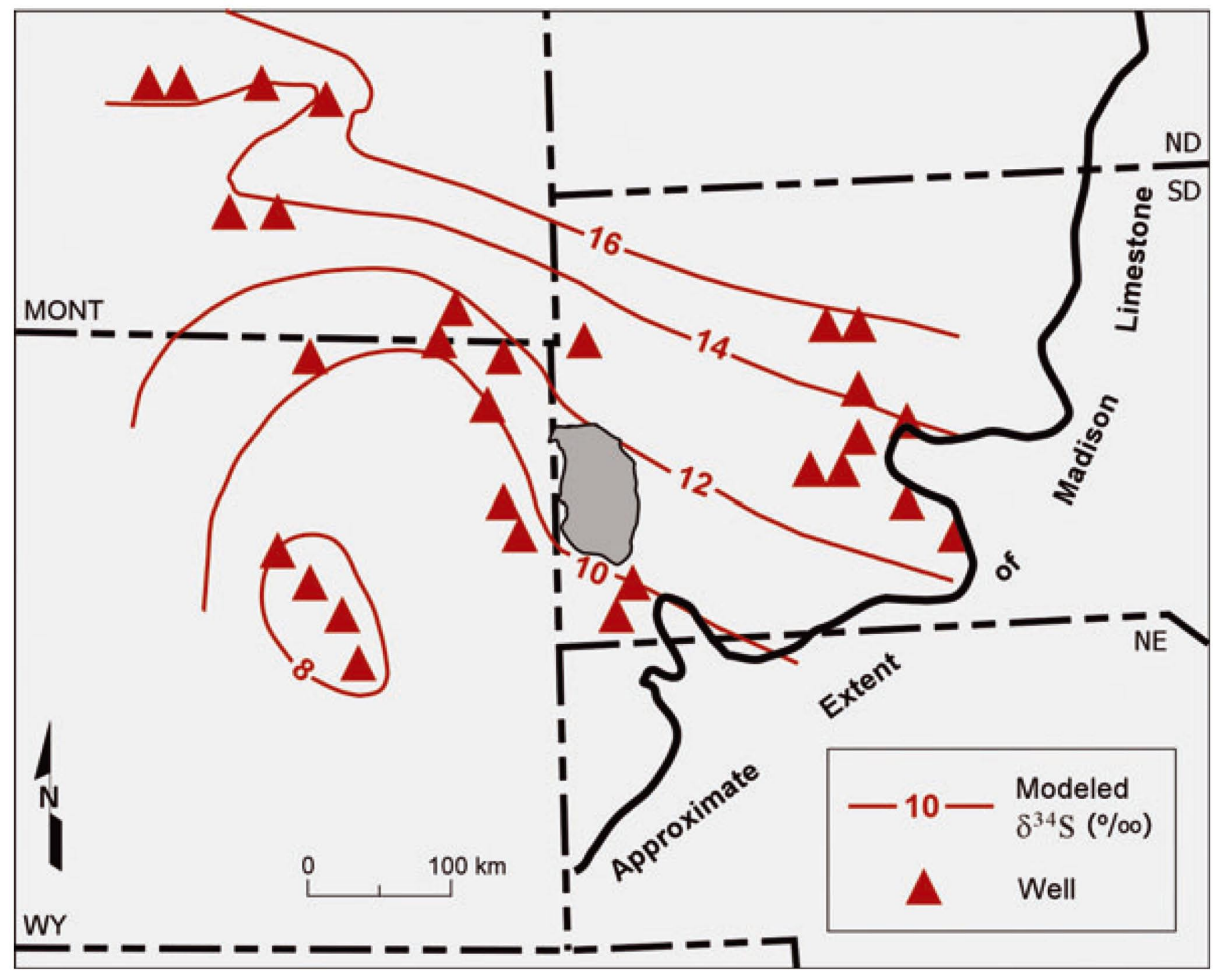

Figure 9. Modeled sulfur isotope composition of groundwater within the Madison Limestone of South Dakota (modified from Plummer et al., 1990).

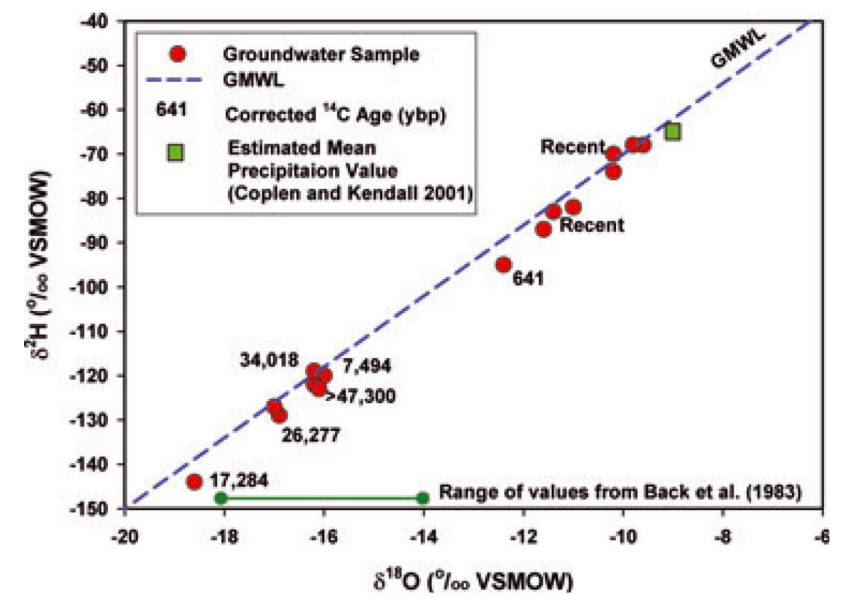

Figure 10. Plot of $\delta^{18} \mathrm{O}$ vs. $\delta^{2} \mathrm{H}$.

rather than bacterially oxidized pyrite. The observed similarity between the western Dakota paleo water and the Madison Aquifer $\delta^{34} \mathrm{~S}$ suggests a similar source for dissolved sulfate in both aquifers is possible.

The high sulfate in groundwater in northeastern Nebraska is likely from recharge from the underlying Madison Aquifer. The regional geochemical survey completed by Gosselin et al. (2001) (Figure 2) thus can be used to determine the southern boundary of influence from the Madison recharge water to the Dakota Aquifer. Just south of the study area, Na-Ca-SO 4 water (Gosselin et al. 2001) has a similar composition to water sampled north of the Sioux Quartzite (Swenson 1968). This is likely a mixing zone be- tween the Madison groundwater with other Dakota Formation water.

Temperature data from several western wells $\left(19^{\circ} \mathrm{C}\right.$ to $30^{\circ} \mathrm{C}$ ) indicate groundwater temperatures higher than expected considering the typical geothermal gradient $\left(1^{\circ} \mathrm{C} / 33\right.$ $\mathrm{m})$. Higher than expected temperatures have also been noted in the Madison Aquifer in central South Dakota, near the area where Madison water is recharging the Dakota (Back et al. 1983).

\section{Oxygen and Deuterium}

The oxygen and deuterium signatures of groundwater from the western, confined portion of the study area (Figure 5a) are more depleted than that of the average signature of modern precipitation. This indicates the water could not have been recharged locally under present climate conditions. However, if this water was indeed recharged in the Black Hills region, as the sulfur data suggest, the isotope composition should reflect differences in altitude and associated climate and would be lighter than water recharged in eastern Nebraska. Depleted isotope values have also been attributed to Pleistocene glacial recharge (Person et al. 2007). See discussion below.

However, Back et al. (1983) reported stable oxygen and deuterium values for groundwater in the Madison Aquifer in the Black Hills region ranging from $-13.2 \%$ o to $-18.2 \%$ o (Figures 10 and 11). Madison groundwater sampled from wells on the eastern slope of the Black Hills is closer to $-13.2 \%$, whereas groundwater sampled in central South 


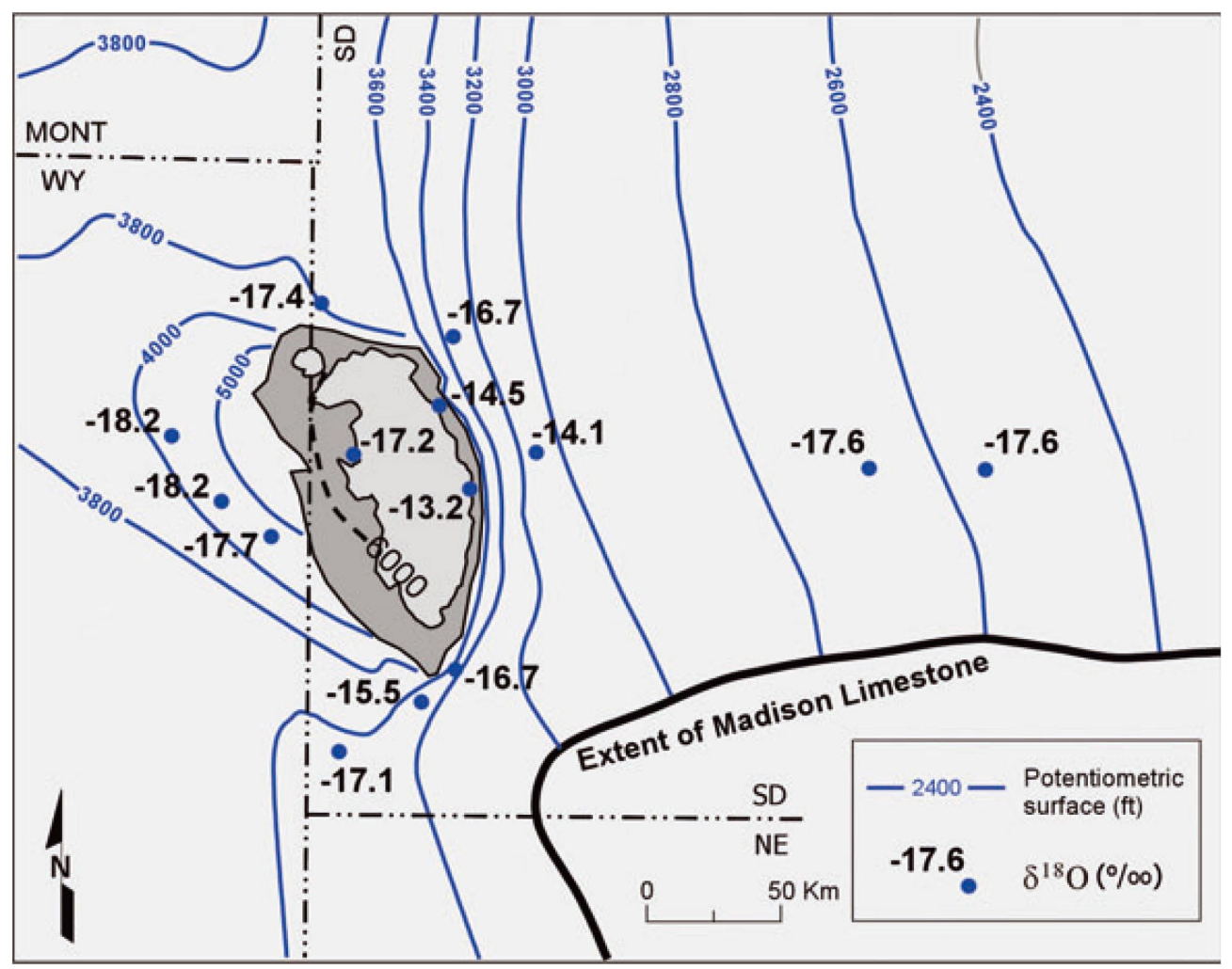

Figure 11. Oxygen isotope composition of groundwater within the Madison Limestone of South Dakota (modified from Back et al., 1983).

Dakota is around $-17 \%$. These central South Dakota Madison water is a mixture of water from the eastern slope of the Black Hills and water from the southwestern and southern slopes. These values are similar to the depleted values found under the confined portions of the study area, and support a Black Hills origin for this water.

\section{Strontium and Chlorine}

Isotopes of strontium and chlorine are often useful in determining water-rock interaction and evolution of groundwater flow systems (Franklyn et al. 1991; Eggenkamp 1994; Frape et al. 1998). The available strontium isotopic data $\left({ }^{87} \mathrm{Sr} /{ }^{86} \mathrm{Sr}\right)$ neither support nor refute a Madison origin for the high $\mathrm{SO}_{4}$ water in the study area (Figure 5e). Strontium isotopic values vary between 0.71019 and 0.71106 in the portion of the study area with high $\mathrm{SO}_{4}$ water (Gosselin et al. 2004). These values are much higher than those observed in the Dakota Aquifer in central and southern Nebraska (0.70880 to 0.70983$)$, western Nebraska (0.70800 to 0.70826), or the Pennsylvanian Madison Formation and anhydrites (0.70809 to 0.70908) (Gosselin et al. 2004; Frost and Toner 2004; Jacobson and Wasserburg 2005). Similarly, low values for Pennsylvanian limestone were reported in central and southern Nebraska (0.70886) (Gosselin et al. 2004). Younger Madison Aquifer water in South Dakota and Wyoming has reported higher $\mathrm{Sr}$ isotopic values (0.70873 to $0.71619)$, although more evolved groundwater is on the low end, owing to interaction with the aquifer rock and anhydrite (Frost and Toner 2004; Jacobson and Wasserburg 2005). The strontium isotopic data indicate a unique origin for the $\mathrm{Ca}-\mathrm{SO}_{4}$ water in northern Nebraska compared with most other Madison or Dakota water or rock material.

It is possible that the higher strontium isotopic values observed in the water in the study area (Figure 5e) are a result of mixing between the northern Nebraska water $\mathrm{Sr}$ and various rock Sr. Unoxidized Dakota Aquifer rock has a higher ${ }^{87} \mathrm{Sr} /{ }^{86} \mathrm{Sr}$ ratio $(0.71035)$ than oxidized aquifer material (0.70957) (Gosselin et al. 2004). This could include water that has interacted with unoxidized Dakota and either oxidized Dakota or Madison Aquifer material. This is expected for long-term interaction with the rock in these aquifers, as suggested by Gosselin et al. (2004).

The unique origin/evolutionary path of the $\mathrm{Ca}-\mathrm{SO}_{4}$ groundwater in the study area as compared with Dakota groundwater across the rest of Nebraska is also supported by limited $\delta^{37} \mathrm{Cl}$ data obtained from the DAK groundwater samples of Gosselin et al. (2001). Stable chlorine isotope values from the Dakota Aquifer in the $\mathrm{Ca}-\mathrm{SO}_{4}$ zone in the study area $(-0.42 \%$ o to $-0.34 \%$ SMOC) are significantly lower compared with values in central $(+0.04 \%$ o SMOC) or western $\left(+0.23 \%\right.$ o to $+0.36 \%$ o SMOC) regions. Although no $\delta^{37} \mathrm{Cl}$ data are available from the Madison Aquifer, the significantly different values in the study area suggest a unique evolutionary path for the Ca-SO $\mathrm{SO}_{4}$ water compared with Dakota Aquifer groundwater across the state of Nebraska. 
Carbon-14

Carbon-14 values (as PMC), and subsequent calculated water ages (as ybp), suggest that groundwater from the western, confined region of the Dakota Aquifer was recharged during the Pleistocene Epoch (Figure 5d). In some instances, isotopically depleted water associated with artesian conditions has been attributed to recharge of melting continental glacial ice during the last ice age (Iles 1982; Siegel and Mandle 1984; Siegel 1991; Person et al. 2007). However, the values attributed to glacial melt water were more enriched $\left(\delta^{18} \mathrm{O}=-15 \%\right.$ o to $-10 \%$ o SMOW $)$ than those observed in the western portion of the study area. Glacial advance during the last glacial maximum stopped at the Missouri River, the northern boundary of the study area (Boellstorff 1978), thus the potential for glacial recharge affecting water in the study area was considered. However, most of the ${ }^{14} \mathrm{C}$ ages from the group of older water indicate recharge occurred in an interglacial period for the area. Although the groundwater with the oldest ${ }^{14} \mathrm{C}$ date is located near the middle of the study area, sample resolution was not sufficient to investigate individual flowpaths. Clearly, groundwater mixing resulting in age dilution from an influx of older water from the confining shales is possible (Bethke and Johnson 2002a, 2002b), and if present, groundwater ages estimated using ${ }^{14} \mathrm{C}$ cannot be interpreted as actual groundwater recharge ages. Even if such mixing did occur, however, the Dakota groundwater is still much too old to have resulted from recharge from melting glacial ice during the most recent continental glaciation. Groundwater ages are more consistent with and more indicative of transport over a longer flowpath over the approximate water age. The intermediate age water occurred near the boundary between the area where the Dakota Formation outcrops and is confined. Thus, the intermediate age groundwater likely results from mixtures of older confined groundwater, whose chemistry is derived from the Madison and Dakota Aquifers upgradient and more recently recharged groundwater that occurs along the edge of the confined portion of the aquifer.

Independent of the age estimations using carbon isotopes, sulfur and stable isotopic data also suggested that the artesian conditions and isotopically depleted water were related to Dakota Aquifer recharge from the Black Hills and subsequent flow and chemical evolution within the underlying Madison Aquifer. If glacial melt water recharge gave rise to the depleted $\delta^{18} \mathrm{O}$ and $\delta^{2} \mathrm{H}$ values, then it would be reasonable to expect the sulfur isotopic data $\left(\delta^{34} \mathrm{~S}, \delta^{18} \mathrm{O}-\mathrm{SO}_{4}\right.$; Figure 8$)$ to be characteristic of water that had derived its dissolved sulfur composition from the bacterial oxidation of pyrite found within the overlying and confining shales, rather than a marine evaporite origin, consistent with Madison Aquifer recharge.

\section{Groundwater Flow Estimation Validation}

Chemical and isotopic evidence suggests that groundwater in the Great Plains (Dakota) Aquifer of northeastern Ne- braska was recharged in the Black Hills of South Dakota, and subsequently derived its dissolved solutes during transport within the Madison and Dakota Aquifers. Carbon-14 ages of ground water in the study area suggest that this recharge occurred a mere 20,000 to more than 40,000 years ago. But is this physically reasonable given the distance and the hydraulic properties of the various aquifers? And, what is the degree of mixing of various aged water during migration and/or sampling? Such questions are typically answered using a regional numerical flow and transport model, which is not currently available for this system. In the absence of such a model, a simple application of Darcy's equation provides insight into the travel times necessary to transport groundwater from the Black Hills region, through the Madison Aquifer and subsequently through the Dakota Aquifer into the study are in northeastern Nebraska, and provides a check on the carbon-14 ages and the potential for "age dilution" due to mixing of water of varying age.

The lateral distance from the eastern Black Hills region to the western portion of the study area in northeastern Nebraska is approximately $450 \mathrm{~km}$ (Figure 1). It should be noted that this distance does not represent the actual travel distance along the bedding planes within the aquifer. However, vertical variations on the order of tens of meters are quite small compared to the horizontal distance, and thus, this simplification should not greatly affect the computation at this level of interest and accuracy. Using the corrected carbon-14 ages (Table 2) for the wells in the western portion of the study area (wells 11 to 13), it took groundwater between 32,700 and 47,300 years to flow from the recharge zone east of the Black Hills to the discharge zone in northeastern Nebraska. This would require groundwater velocities to be approximately between 9.5 and $13.8 \mathrm{~m} /$ year.

To facilitate the calculation of groundwater velocities and travel times for the Madison and Dakota Aquifers, the flowpath distance was divided into two segments. The first 200-km segment represents the distance over which flow would be in the Madison Aquifer extending from the Black Hills region eastward to the extent of the Madison Formation (Figure 9). The second $250-\mathrm{km}$ segment represents the distance over which groundwater flow would be in the Dakota Aquifer extending from the eastern extent of the Madison Aquifer to the center of the western portion of the study area near well 12 (Figures 1 and 9).

For each segment, groundwater velocities were calculated using the equation $v=(-K / n) H$, where $K$ is the hydraulic conductivity of the aquifer $(\mathrm{m} / \mathrm{s}), n$ is aquifer porosity, and $H$ is the regional hydraulic gradient in the direction of groundwater flow within the various aquifers. Travel times were then calculated by dividing the length of each segment of the overall travel distance by the calculated groundwater velocity, $v$. Porosity values for the Madison Aquifer (3.5\% to 7.5\%) were taken from Konikow (1985). Hydraulic gradient (0.004) and conductivity values $\left(2.4 \times 10^{-6}\right.$ to $\left.91 \times 10^{-6} \mathrm{~m} / \mathrm{s}\right)$ for the Madison Aquifer were taken from the wells in flowpath number 8 in Table 12 of Plummer et al. (1990). A Dakota Aquifer hydraulic gradi- 
ent (0.0015) was estimated using Figure 12a of Bredehoeft et al. (1983). Dakota Aquifer hydraulic conductivity (0.64 $\times 10^{-5}$ to $3.35 \times 10^{-5}$ ) and porosity values (19.1\% to $\left.28.5 \%\right)$ were taken from Table 2 of Bredehoeft et al. (1983).

The results of these simplified calculations suggest aquifer velocities of 8.7 to $15.3 \mathrm{~m} /$ year for the Madison Aquifer and 1.6 to $5.6 \mathrm{~m} /$ year for the Dakota Aquifer. These velocities are similar to the estimated groundwater velocities calculated using this study's ${ }^{14} \mathrm{C}$ values and travel distances. However, summing the age range estimates of the two segments (Madison: 13,067 to 23,122 years; Dakota: 44,962 to 157,723 years) of the total flow length gives a range of total travel times of between 58,029 and 180,845 years. If aquifer hydraulic parameters are such to result in the shorter travel times, the Darcy estimated and ${ }^{14} \mathrm{C}$ calculated travel times are similar, indicating that the ${ }^{14} \mathrm{C}$ ages do reflect the time of recharge and that the sampled parcels of water are not mixtures of older and younger water. However, if aquifer hydraulic parameters resulted in the longer travel times, comparison of the estimated results suggests that the corrected groundwater ${ }^{14} \mathrm{C}$ ages are too young, and thus, the sampled groundwater is a mixture of older and younger water. It should be noted that discrepancies between the ${ }^{14} \mathrm{C}$ ages and the Darcy estimate ages do not nullify the Black Hills origin hypothesis, which is supported independently by other chemical and isotopic evidence. Rather, age differences simply indicate that in this system, sampled groundwater ${ }^{14} \mathrm{C}$ ages may not accurately represent the aquifer residence time nor the time of recharge-a conclusion reached in other studies where ${ }^{14} \mathrm{C}$ ages were found to differ from modeled flowpath travel times (Bethke and Johnson 2008). The calculations also indicate longer travel times that are beyond the dating range of the carbon-14 method (typically assumed to be about 50,000 years). This suggests that the groundwater ages determined in the study are nearing the upper limit of detection by this dating method, and thus may need to be interpreted with greater caution. Again, this does not negate the proposed origin theory, but suggests that more time would be needed for transport and that carbon-14 dating may not be adequate to delineate travel times within this aquifer system.

\section{Conclusions}

The physical, chemical, and isotopic evidence collected in this study supports the conclusion of Swenson (1968) that present-day groundwater (or at least a portion thereof) withdrawn from the Dakota Aquifer in South Dakota was recharged several tens of thousands (to perhaps hundreds of thousands) of years ago in the Black Hills. This study extends the area affected by Black Hills recharge in the Dakota Aquifer into northeastern Nebraska. Following recharge, groundwater traveled eastward first through the Madison Aquifer and subsequently through the Dakota Aquifer toward a regional discharge zone in northeastern Nebraska. $\mathrm{Ca}-\mathrm{SO}_{4}$ groundwater compositions and stable isotope ratios $\left(\delta^{2} \mathrm{H}, \delta^{18} \mathrm{O}, \delta^{34} \mathrm{~S}, \delta^{18} \mathrm{O}-\mathrm{SO}_{4}\right)$ are all similar to those of groundwater presently withdrawn from the Madison Aquifer and are consistent with the proposed theory of regional migration from the Black Hills. Groundwater sampled in Nebraska, which is not Ca-SO type, has distinctly different isotopic composition $\left(\delta^{2} \mathrm{H}, \delta^{18} \mathrm{O}, \delta^{34} \mathrm{~S}, \delta^{18} \mathrm{O}-\mathrm{SO}_{4}\right)$. Thus, Ca-SO ${ }_{4}$-type water in the Dakota Aquifer in northeastern Nebraska and South Dakota is indicative of water recharging from the underlying Madison Aquifer. As a next step, these conclusions should be tested by construction of a regional flow and reactive transport model of the region and of Madison-Dakota Aquifer interactions.

\section{Acknowledgments}

We wish to thank the Agricultural Research Division of the University of Nebraska-Lincoln's Institute for Agriculture and Natural Resources for helping to fund this project in part via an Undergraduate Honors Student Research Program award to the first author in 1998. Thanks to Scott Summerside and Marv Carlson, of the Nebraska Conservation and Survey Division, for assisting the first author with state well files and information related to the thermal area of North-Central Nebraska. Dee Ebbeka and Ann Mack are thanked for drafting some of the figures. The second author thanks Dr. Mark Person for discussions regarding basinal scale groundwater flow and paleohydrogeology. We thank the various well owners for allowing us access to their wells and for their assistance in well location. Finally, we thank editor Mary Anderson and reviewers Niel Plummer, Chris Neuzil, and Tamie Weaver for their technical reviews and insightful comments, which helped to strengthen and improve this manuscript.

Supporting Information follows the References.

\section{References}

Back, W., B. B. Hanshaw, L. N. Plummer, P. H. Rahn, C. T. Rightmire, M. Rubin. 1983. Process and rate of dedolomitization: Mass transfer and ${ }^{14} \mathrm{C}$ dating in a regional carbonate aquifer. Geological Society of America Bulletin 94 no. 12: 1415-1429.

Barkley, R. C. 1953. Artesian conditions in area surrounding the Sioux Quarzite Ridge. South Dakota State Geological Survey Report of Investigations No. 72, Vermillion, South Dakota: South Dakota State Geological Survey.

Bethke, C. M., T. M. Johnson. 2008. Groundwater age and groundwater age dating. Annual Review of Earth and Planetary Sciences 36, 121-152.

Bethke, C. M., T. M. Johnson. 2002a. Paradox of groundwater age: Correction. Geology 30 no. 4: 385-388.

Bethke, C. M., T. M. Johnson. 2002b. Ground water age, Technical Commentary. Ground Water 40 no. 4: 337-339.

Boellstorff, J. 1978. A need for redefinition of North American Pleistocene stages. Transactions-Gulf Coast Association of Geological Societies 28, 65-74.

Bredehoeft, J. D., C. E. Neuzil, C. P. Milly. 1983. Regional flow in the Dakota Aquifer: A study of the role of confining layers. U. S. 
Geological Survey Water-Supply Paper 2237. Reston, Virginia: USGS.

Burchett, R. R., R. K. Pabian. 1991. Geologic Bedrock Map of Nebraska. Lincoln: Conservation and Survey Division, University of Nebraska-Lincoln.

Clark, I. D., P. Fritz. 1997. Environmental Isotopes in Hydrogeology, 328, Boca Raton, Florida: Lewis Publishers, CRC Press.

Coleman, M. L., T. J. Shepherd, J. J. Durham, J. E. Rouse, G. R. Moore. 1982. Reduction of water with zinc for hydrogen isotope analysis. Analytical Chemistry 54 no. 6: 993-995.

Darton, N. H. 1909. Geology and underground waters of South Dakota. USGS Water Supply Paper 227. Reston, Virginia: USGS.

Darton, N. H. 1905. Geology and underground water resources of the central Great Plains. USGS Professional Paper 32. Reston, Virginia: USGS.

Eggenkamp, H. G. M. 1994. The geochemistry of chlorine isotopes. Ph. D. diss., Utrecht University, The Netherlands.

Epstein, S., T. K. Mayeda. 1953. Variations of the ${ }^{18} \mathrm{O} /{ }^{16} \mathrm{O}$ ratio in natural waters. Geochimica et Cosmochimica Acta 5 no. 5: 213-224.

Fontes, J. -Ch., J. -M. Garnier. 1979. Determination of the initial ${ }^{14} \mathrm{C}$ activity of total dissolved carbon: A review of existing models and a new approach. Water Resources Research 15, 399-413.

Franklyn, M. T., R. H. McNutt, D. C. Kamineni, M. Gascoyne, S. K. Frape. 1991. Groundwater ${ }^{87} \mathrm{Sr} /{ }^{86} \mathrm{Sr}$ values in the Eye-Dashwa Lakes Pluton, Canada: Evidence of Plagioclase-water reactions. Chemical Geology 86, 111-122.

Frape, S. K., G. Bryant, P. Durance, J. C. Ropchan, J. Doupe, R. Blomqvist, P. Nissinen, J. Kaija. 1998. The source of stable chlorine isotopic signatures in groundwaters from crystalline shield rocks. In Proceedings of the $9^{\text {th }}$ International Symposium on Water Rock Interaction, 223-226, Rotterdam, Netherlands: A. A. Balkema Publishers.

Frost, C. D., R. N. Toner. 2004. Strontium isotopic identification of water-rock interaction and ground water mixing. Ground $\mathrm{Wa}-$ ter 42 no. 3: 418-432.

Gosselin, D. C., F. E. Harvey, C. Frost, R. Stotler, P. A. Macfarlane. 2004. Strontium isotope geochemistry in the central part of the Great Plains (Dakota) Aquifer, U. S. A. Applied Geochemistry 19 no. 3: 359-377.

Gosselin, D. C., F. E. Harvey, C. Frost. 2001. Geochemical evolution of ground water in the Great Plains (Dakota) Aquifer of Nebraska: Implications for the management of a regional aquifer system. Ground Water 39 no. 1: 98-108.

Gupta, S. K., H. A. Polach. 1985. Radiocarbon Dating Practices at ANU. Handbook, Radiocarbon Laboratory, Research School of Pacific Studies, 173. Canberra, Australia: Australian National University.

Harvey, F. E. 2001. Use of NADP archive samples to determine the isotope composition of precipitation: Characterizing the meteoric input function for use in ground water studies. Ground Water 39 no. 3: 380-390.

Helgesen, J. O., D. G. Jorgensen, R. B. Leonard, D. C. Signor. 1984. Regional study of the Dakota Aquifer (Darton's Dakota revisited), in geohydrology of the Dakota Aquifer. In Proceedings of the C. V. Theis Conference on Geohydrology, ed. D. G. Jorgensen, and D. C. Signor, 69-76. Worthington, Ohio: National Water Well Association.

Helgesen, J. O., D. G. Jorgensen, R. B. Leonard, D. C. Signor. 1982. Regional study of the Dakota Aquifer (Darton's Dakota revisited). Ground Water 20 no. 4: 410-414.

Iles, D. L. 1982. Pleistocene recharge to Dakota Formation in Lincoln County, South Dakota. In Proceedings of the C. V. Theis
Conference on Geohydrology, ed. D. G. Jorgensen, and D. C. Signor, 135-146. Worthington, Ohio: National Water Well Association.

Ingerson, R., F. J. Pearson. 1964. Estimation of age and rate of motion of groundwater by the ${ }^{14} \mathrm{C}$ method. In Recent Research in the Field of Hydrosphere, Atmosphere and Nuclear Geochemistry, ed. Y. Miyake, and T. Koyama, 263-283. Tokyo: Maruzen.

Jacobson, A. D., G. J. Wasserburg. 2005. Anhydrite and the Sr isotopic evolution of groundwater in a carbonate aquifer. Chemical Geology 214, 331-350.

Jorgenson, D. G., J. O. Helgeson, J. L. Imes. 1993. Regional aquifers in Kansas, Nebraska, and Parts of Arkansas, Colorado, Missouri, New Mexico, Oklahoma, South Dakota, Texas, Wyoming-Geohydrologic framework. USGS Professional Paper 1414-B. Reston, Virginia: USGS.

Kalin, R. M. 2000. Radiocarbon dating of groundwater systems. In Environmental Tracers in Subsurface Hydrology, ed. P. Cook and A. L. Herczeg, 111-144. Norwell, Massachusetts: Kluwer Academic Publishers.

Kendall, C., T. B. Coplen. 2001. Distribution of oxygen-18 and deuterium in river waters across the United States. Hydrologic Processes 15 no. 7: 1363-1393.

Konikow, L. F. 1985. Process and rate of dedolomitization: Mass transfer and ${ }^{14} \mathrm{C}$ dating in a regional carbonate aquifer: Extended interpretation. Geological Society of America Bulletin 96, 1096-1098.

Krouse, H. R., B. Mayer. 2000. Sulphur and oxygen isotopes in sulphate. In Environmental Tracers in Subsurface Hydrology, ed. P. Cook and A. L. Herczeg, 195-231. Norwell, Massachusetts: Kluwer.

Leonard, R. B., D. C. Signor, D. G. Jorgensen, J. O. Helgesen . 1984. Geohydrology and hydrochemistry of the Dakota Aquifer, central United States. In Geohydrology of the Dakota Aquifer, Proceedings of the C. V. Theis Conference on Geohydrology, ed. D. G. Jorgensen and D. C. Signor, 229-237. Worthington, Ohio: National Water Well Association.

Mook, W. G., van der Plicht, J. 1999. Reporting ${ }^{14} \mathrm{C}$ activities and concentrations. Radiocarbon 41 no. 3: 227-239.

Munnich, K. O. 1957. Messung des ${ }^{14} \mathrm{C}$-Gehaltes von hartem Grundvasser. Naturwissenschaften 44, 32-34.

Parkhurst, D. L., C. A. J. Appelo. 1999. User's guide to PHREEQC (Version 2)-a computer program for speciation, batch-reaction, onedimensional transport, and inverse geochemical calculations. USGS Water Resources Investigations Report 99-4259. Reston, Virginia: USGS.

Pearson, F. J. 1965. Use of C-13/C-12 ratios to correct radiocarbon ages of material initially diluted by limestone. In Proceedings of the $6^{\text {th }}$ International Conference on Radiocarbon and Tritium Dating, 357. Washington: Pullman.

Pearson, F. J., B. B. Hanshaw. 1970. Sources of dissolved carbonate species in groundwater and their effects on carbon-14 dating. In Isotope Hydrology 1970, IAEA Symposium 129, March 1970, 271-286. IAEA, Vienna: IAEA.

Person, M., J. McIntosh, V. Bense, V. H. Remenda. 2007. Pleistocene hydrology of North America: The role of ice sheets in reorganizing groundwater flow systems. Reviews of Geophysics 45 no. 3: doi: RG3007, 10. 1029/2006RG000206.

Plummer, L. N., E. C. Prestemon, D. L. Parkhurst. 1994. An interactive code (NETPATH) for modeling net geochemical reactions along a flowpath, version 2. 0. USGS Water Investigations Report 944169. Reston, Virginia: USGS.

Plummer, L. N., J. F. Busby, R. W. Lee, B. B. Hanshaw. 1990. Geochemical modeling of the Madison Aquifer in parts of Mon- 
tana, Wyoming, and South Dakota. Water Resources Research 26 no. 9: 1981-2014.

Shakur, M. A. 1982. $\delta^{34} \mathrm{~S}$ and $\delta^{18} \mathrm{O}$ variations in terrestrial sulfates. $\mathrm{Ph}$. D. thesis, University of Calgary.

Sheppard, S. F. M., R. L. Nielsen, H. P. Taylor. 1969. Oxygen and hydrogen isotope ratios of clay minerals from porphyry copper deposits. Economic Geology 64, 755-777.

Siegel, D. I. 1991. Evidence for dilution of deep, confined groundwater by vertical recharge of isotopically heavy Pleistocene water. Geology 19 no. 5: 433-436.

Siegel, D. I., R. J. Mandle. 1984. Isotopic evidence for glacial meltwater recharge to the Cambrian-Ordovician Aquifer, NorthCentral United States. Quaternary Research 22 no. 3: 328-335.

Stiff, H. A. Jr. 1951. The interpretation of chemical water analysis by means of patterns. Journal Petroleum Technology 3 no. 10: Section 1, 15-17.

Stuiver, M., H. A. Polach. 1977. Discussion: Reporting of ${ }^{14} \mathrm{C}$ Data. Radiocarbon 19 no. 3: 355-363.

Swenson, F. A. 1968. New theory of recharge to the artesian basin of the Dakotas. Geological Society of America Bulletin 79 no. 2: 163-182.

Tamers, M. A. 1967. Surface-water infiltration and groundwater movement in arid zones of Venezuela. In Isotopes in Hydrology, 339-351. Vienna: IAEA.

Taylor, C. B. 1977. Tritium enrichment of environmental waters by electrolysis: Development of cathodes exhibiting high isotopic separation and precise measurement of tritium enrichment factors. In Proceedings of the International Conference of Low-Radioactivity Measurements and Applications, 131-140. Bratislava: Slovenski Pedagogicke Nakladatelstvo.

Upham, W. 1895. The glacial Lake Agassiz. USGS Monograph 25.

Yanagisawa, F., H. Sakai. 1983. Thermal decomposition of barium sulfate vanadium pentaoxide silica glass mixtures for preparation of sulfur-dioxide in sulfur isotope ratio measurements. Analytical Chemistry 55 no. 6: 985-987.

Zhu, C., W. M. Murphy. 2000. On radiocarbon dating of ground water, Technical Commentary. Ground Water 38 no. 6: 802-804.

\section{Supporting Information}

Ion Detection Limits

Practical detection limits for ions with AA and IC were $0.1 \mathrm{mg} /$ L. At the laboratory where these analyses were performed, they measure the concentrations of each sample in replicates compared to a standard with a certain tolerance (typically $5 \%$ ). If the sample is outside of this range, it is re-run. They then report to us the average of the replicate samples with a precision equal to the detection limit of either the AA or IC depending on the methodology. Thus, each individual well sample had a different precision than every other sample. So values were rounded up to negate any errors or spread in the data around the detection limit. For example, if the lab reports Ca values of 23.59 we use 24 . The precision is still 0.01 or so for the analysis, but we simplify the number. The results had values reported to various levels of precision so it's impossible to state one precision value for the entire data set for each element. Thus values are reported as 2.11, 21.1, 210, 2100 depending on the concentration and the general detection limits of the specific element and analysis. So for one sample the precision might be 0.1 for another of the same element, it might be 100 if it's a highly concentrated sample. A charge balance was calculated for each analysis to evaluate analytical error, and to determine if all the major ions were accounted for in the analysis.

Supplemental Table SI. Saturation Indices calculated by PHREEQC (Parkhurst and Appelo 1999) for Dakota Aquifer ground water sampled in this study.

\begin{tabular}{|c|c|c|c|c|c|c|}
\hline Well & $\log \mathrm{pCO}_{2}$ & \multicolumn{5}{|c|}{ Saturation Indices } \\
\hline I & -1.75 & -1.73 & -0.03 & -0.60 & -1.47 & -0.14 \\
\hline 3 & -1.75 & -1.98 & -0.07 & -0.54 & -1.73 & -0.01 \\
\hline 4 & -1.88 & -1.53 & 0.12 & -0.23 & -1.28 & 0.03 \\
\hline 5 & -1.63 & -1.95 & 0.00 & -0.42 & -1.69 & 0.05 \\
\hline 8 & -0.99 & -1.26 & -0.92 & -2.30 & -1.01 & -0.34 \\
\hline 9 & -2.04 & -0.90 & -0.13 & -0.80 & -0.65 & -0.29 \\
\hline 10 & -1.46 & -0.78 & 0.36 & 0.18 & -0.53 & -0.31 \\
\hline II & -2.14 & -0.76 & 0.07 & -0.22 & -0.56 & -0.37 \\
\hline 12 & -1.24 & -0.84 & -0.80 & -2.05 & -0.61 & -0.43 \\
\hline
\end{tabular}

